This item was submitted to Loughborough's Research Repository by the author.

Items in Figshare are protected by copyright, with all rights reserved, unless otherwise indicated.

\title{
Treatment of aqueous solutions of 1,4-dioxane by ozonation and catalytic ozonation with copper oxide (CuO)
}

PLEASE CITE THE PUBLISHED VERSION

https://doi.org/10.1080/09593330.2018.1538259

\section{PUBLISHER}

(C) Taylor and Francis

\section{VERSION}

AM (Accepted Manuscript)

\section{PUBLISHER STATEMENT}

This is an Accepted Manuscript of an article published by Taylor \& Francis in Environmental Technology on 29 Oct 2018, available online: https://doi.org/10.1080/09593330.2018.1538259

\section{LICENCE}

CC BY-NC-ND 4.0

\section{REPOSITORY RECORD}

Scaratti, Gidiane, Alex Basso, Richard Landers, Pedro J.J. Alvarez, Gianluca Li-Puma, and Regina F.P.M. Moreira. 2018. "Treatment of Aqueous Solutions of 1,4-dioxane by Ozonation and Catalytic Ozonation with Copper Oxide (cuo)". Loughborough University. https://hdl.handle.net/2134/36395. 


\title{
TREATMENT OF AQUEOUS SOLUTIONS OF 1,4-DIOXANE BY OZONATION AND CATALYTIC OZONATION WITH COPPER OXIDE (CuO)
}

\author{
SCARATTI, G. ${ }^{1^{*}}$; BASSO, A. ${ }^{1}$; LANDERS, R. ${ }^{2}$; ALVAREZ, P. ${ }^{3}$; LI PUMA, G ${ }^{4}$; \\ MOREIRA, R. F. P. M. ${ }^{1}$
}
${ }^{1}$ Department of Chemical and Food Engineering, Federal University of Santa Catarina, Florianópolis, SC, Brazil
${ }^{2}$ Institute of Physics Gleb Wataghin, University of Campinas, Campinas, SP, Brazil
${ }^{3}$ Department of Civil and Environmental Engineering, Rice University, Houston, TX, USA
${ }^{4}$ Environmental Nanocatalysis \& Photoreaction Engineering, Department of Chemical Engineering, Loughborough University, Loughborough, United Kingdom

*Corresponding author: Tel: +55 4837216441

E-mail: gidiane@gmail.com; basso54ster@gmail.com; landers@ifi.unicamp.br; alvarez@rice.edu; g.lipuma@lboro.ac.uk; regina.moreira@ufsc.br 


\begin{abstract}
In this study, treatment for the removal of 1,4-dioxane by ozone and by catalytic ozonation using $\mathrm{CuO}$ as the catalyst was investigated. While the removal of 1,4-dioxane was small $(20 \%)$ and mineralization negligible after $6 \mathrm{~h}$ of ozonation treatment, the removals of 1,4-dioxane and total organic carbon increased by factors of 10.35 and 81.25, respectively, after catalytic ozonation in the presence of $\mathrm{CuO}$. The mineralization during catalytic ozonation was favored at $\mathrm{pH} 10\left(94.91 \mathrm{~min}^{-1}\right)$, although it proceeded even at $\mathrm{pH}$ $3\left(54.41 \mathrm{~min}^{-1}\right)$. The $\mathrm{CuO}$ catalyst decreased the equilibrium concentration of soluble ozone and favored its decomposition to reactive oxidative species. Radical scavenging experiments demonstrated that superoxide radicals were the main species responsible for the degradation of 1,4-dioxane. Further scavenging experiments with phosphate confirmed the presence of Lewis active sites on the surface of $\mathrm{CuO}$, which were responsible for the adsorption and decomposition of ozone. The reaction mechanism proceeded through the formation of ethylene glycol diformate, which quickly hydrolyzed to ethylene glycol and formic acid as intermediate products. The stability of $\mathrm{CuO}$ indicated weak copper leaching and high catalytic activity for five recycling cycles. The toxicity of the water, assessed by Vibrio fischeri bioluminescence assays, remained the same (low toxicity) after catalytic ozonation while it increased after treatment with ozonation alone.
\end{abstract}

Keywords: 1,4-dioxane; groundwater contamination; catalytic ozonation; copper oxide; advanced oxidation processes. 


\section{Introduction}

1,4-dioxane is a synthetic cyclic ether traditionally used as a chlorinated solvent stabilizer. It is a contaminant often detected in groundwater or at sites contaminated with 1,1,1-trichloroethane or trichloroethene. 1,4-Dioxane has been detected in municipal water supply wells [1] and river, ocean and groundwater samples [2] in concentrations in the range of 1.9 to $2,100 \mathrm{ppb}$. These contaminated sites are typically in locations where degreasing operations associated with military equipment or electronic components have taken place, or near dry cleaners and industrial complexes. 1,4-Dioxane is also a common by-product of chemical processes involving the production or use of ethylene glycol [3,4] and, as a result, can also be present in industrial wastewaters, some of them with high 1,4dioxane concentrations of around $250 \mathrm{ppm}$ [5].

Concern regarding the impact of 1,4-dioxane on the environment has increased in recent years, particularly since this compound has been classified as a priority hazardous pollutant and a probable human carcinogen [6,7]. 1,4-Dioxane has a high aqueous solubility, low vapor pressure and a boiling point similar to that of water $[3,4,8,9]$. It is a relatively bio-recalcitrant and persistent organic molecule that is resilient to treatment by conventional processes, such as adsorption onto activated carbon or air stripping. Consequently, advanced treatment processes for the degradation of 1,4-dioxane in contaminated groundwater have been investigated, including biodegradation [10], chemical oxidation by Fenton and hydrogen peroxide/UV processes $[11,12]$, ozone $\left(\mathrm{O}_{3}\right)$ with hydrogen peroxide, persulfate and peroxone-activated persulfate $[13,14,15]$. When $\mathrm{O}_{3}$ is used as the sole oxidant it has been found to be relatively ineffective, since the 1,4dioxane molecule does not present reacting sites that favor direct attack by $\mathrm{O}_{3}[13,16-$ 19]. However, under basic conditions, ozonation was found to be a more attractive technology in terms of operating cost and COD reduction when compared with 
heterogeneous $\mathrm{Fe}^{0}$-based photo-Fenton and conductive diamond electrochemical oxidation for the pretreatment of 1,4-dioxane-containing wastewater from a chemical manufacturing industry [5].

Catalytic ozonation is an effective advanced oxidation process (AOP) for the removal of organic contaminants from water and wastewater [20-23], owing to its ability to decompose the ozone molecule to highly reactive radical species, which rapidly react with organic contaminants. Several solid catalysts, such as iron oxides [20, 24-26], ceria oxide $[27,28]$, activated carbon $[29,30]$ and $\mathrm{Fe}^{0}[31]$, have been used successfully to catalyze the decomposition of organic compounds in wastewaters using ozone or hydrogen peroxide. In general, the catalytic activity is related to the BET surface area, crystallinity and ability to produce free radicals from ozone or hydrogen peroxide [32]. In addition, catalytic ozonation generally has a low impact on the water quality after treatment and is a process that is easy to implement at the industrial scale at a relatively low cost [33]. The catalytic ozonation of water contaminated with 1,4-dioxane has been reported in only one study, employing activated carbon as the catalyst (efficiency of 1,4dioxane removal was $95 \%$ for 3000 ppm of activated carbon) [29], and the use of metal oxides as catalysts has not been reported.

With regard to metal oxides, copper oxide $(\mathrm{CuO})$ has often been used as an effective ozonation catalyst, since it offers good catalytic properties, favoring a high density of adsorbed hydroxyl groups on the surface, which significantly enhances the decomposition of ozone and the degradation of aqueous organic pollutants [34,21]. In addition, $\mathrm{CuO}$ is inexpensive, chemically stable and presents much lower toxicity in relation to other ozone-activating catalysts [34].

The catalytic mechanism of action of $\mathrm{CuO}$ toward ozone and in the oxidation of organic compounds remains controversial, particularly since the oxidation can follow a 
hydroxyl radical or a non-hydroxyl radical oxidation pathway [27]. In general, hydroxyl radicals $(\cdot \mathrm{OH})$ react quickly and non-selectively with a large number of organic compounds in water, while $\mathrm{O}_{3}$ reacts quickly with unsaturated organic compounds and slowly with saturated ones [32]. However, hydroxyl radicals can also react with ozone $\left(\mathrm{k} \cdot \mathrm{OH}=1 \times 10^{8}-2 \times 10^{9} \mathrm{M}^{-1} \mathrm{~s}^{-1}\right)$ and bicarbonate/carbonate $\left(\mathrm{k} \cdot \mathrm{OH}=8.5 \times 10^{6} / 3.9 \times 10^{8}\right.$ $\mathrm{M}^{-1} \mathrm{~s}^{-1}$ ) [28]. Thus, it is expected that the $\bullet \mathrm{OH}$ reaction with saturated hydrophilic organic species and by-products in the presence of ozone is relatively slow due to the competitive reaction of ${ }^{\bullet} \mathrm{OH}$ and ozone [35].

In this study, the effectiveness of $\mathrm{CuO}$ as catalyst for the decomposition of ozone and degradation of aqueous solutions of 1,4-dioxane through catalytic ozonation was investigated. The morphological, physical, chemical and catalytic properties of the $\mathrm{CuO}$ catalyst were determined using several analytical techniques, including transmission electron microscopy (TEM), X-ray diffraction (XRD), surface area and porosity analysis (BET-BJS), atomic absorption spectrometry (AAS), zeta-potential measurements, Fourier transform infrared spectroscopy (FTIR) and X-ray photoelectron spectroscopy (XPS). The degradation kinetics of 1,4-dioxane, as a function of the $\mathrm{pH}$ and catalyst dosage, was assessed in terms of total organic carbon (TOC) and 1,4-dioxane removal, and the underlying mechanisms of ozonation and catalytic ozonation, the stability and the reusability of the catalyst were investigated. The acute toxicity toward Vibrio fischeri of the water before and after treatment with ozonation and with catalytic ozonation was evaluated to determine the efficiency of the treatment processes for practical water remediation.

\section{Material and Methods}

\section{Chemicals and Materials}


All reagents used were analytical grade and solutions were prepared with deionized water. 1,4-Dioxane (99.99\%) was supplied by Neon (Brazil). Commercial copper oxide (99\% of purity) was purchased from Amorphous and Nanostructures Materials Inc. (Houston, TX, USA). Sodium dihydrogen phosphate $\left(\mathrm{NaH}_{2} \mathrm{PO}_{4}\right)$ was purchased from Vetec (Brazil), 1,4-benzoquinone $\left(\mathrm{C}_{6} \mathrm{H}_{4} \mathrm{O}_{2}\right)$ from Sigma Aldrich (USA), salicylic acid $\left(\mathrm{C}_{7} \mathrm{H}_{6} \mathrm{O}_{3}\right)$ from Reagen (Brazil) and sodium fluoride (NaF) from Synth (Brazil).

\section{Characterization of the catalyst}

The morphology of the $\mathrm{CuO}$ particles was determined by transmission electron microscopy (TEM) (JEOL, JEM-1011). The crystalline phases in the samples were determined by X-ray diffraction (XRD) on a Bruker D2-Phaser diffractometer with CuK $\alpha$ radiation $(\lambda=1.54056 \AA)$, from $10^{\circ}$ to $70^{\circ}$.

The specific surface area $\left(\mathrm{S}_{\mathrm{BET}}\right)$ and pore diameter distribution of the $\mathrm{CuO}$, according to the Barret-Joyner-Halenda $(\mathrm{BJH})$ method, were determined by $\mathrm{N}_{2}$ adsorption-desorption experiments. Analysis was carried out by means of isotherms obtained on an Autosorb 1C (Quantachrome, USA) adsorptometer. Prior to the analysis, the samples were degassed for $12 \mathrm{~h}$ at $140{ }^{\circ} \mathrm{C}$ under vacuum.

The zeta potential $(\xi)$ of aqueous suspensions of $\mathrm{CuO}(0.5 \mathrm{~g}$ of $\mathrm{CuO}$ in $50 \mathrm{~mL}$ of deionized water) as a function of $\mathrm{pH}$ (from 3 to 10 ) was measured using a Stabino NANOflex particle. The zeta potential was determined from the electrophoretic mobility $(\mu)$ based on the Smoluchowski equation. $\mathrm{NaOH}$ and $\mathrm{HCl}(0.01 \mathrm{~N}$ solutions) were used as titration media to automatically adjust the $\mathrm{pH}$ values.

The $\mathrm{Cu}$ content of the catalysts was determined using atomic absorption spectroscopy (AAS). In this procedure, $1.0 \mathrm{mg}$ of the catalyst was solubilized in $20 \mathrm{~mL}$ of concentrated $\mathrm{HNO}_{3}$ and $\mathrm{HCl}$ solution and evaporated to less than $5 \mathrm{~mL}$ [36]. After solubilization, the samples were transferred to volumetric flasks. The volume was 
adjusted to $50 \mathrm{~mL}$ with distilled water and analyzed via AAS with an Agilent 240FSAA spectrometer.

Fourier transform infrared (FTIR) spectra of $\mathrm{CuO}$ before use and after 5 treatment cycles were recorded between 400 and $4000 \mathrm{~cm}^{-1}$ using an FTIR spectrometer (Agilent Technologies - Cary 600 Series).

The X-ray photoelectron spectroscopy (XPS) spectra were obtained with a VSW HA-100 spherical analyzer and $\mathrm{MgK} \alpha$ radiation $(\mathrm{hv}=1253.6 \mathrm{eV})$. The high-resolution spectra were measured with constant analyzer pass energies of $44 \mathrm{eV}$. The pressure during the measurements was always less than $2 \times 10^{-8}$ mbar. The sample was fixed to a stainless steel sample holder with double-faced conducting tape and analyzed without further preparation. Surface charge was corrected, shifting all spectra so that the $\mathrm{C} 1 \mathrm{~s}$ line associated with adventitious carbon was at $284.6 \mathrm{eV}$. Curve fitting was performed using Gaussian line shapes and a Shirley background was subtracted from the data.

\section{Ozonation and catalytic ozonation experiments}

Ozonation experiments were carried out isothermally at $25^{\circ} \mathrm{C}$ in a $1.5 \mathrm{~L}$ glassjacketed vessel (21 cm height and $8 \mathrm{~cm}$ diameter) continuously stirred ( $\sim 500 \mathrm{rpm})$ with a magnetic stirrer (Dist - model DI-03). In a typical procedure, 1.5 L of a 200 ppm 1,4dioxane aqueous solution was transferred into the reactor, the $\mathrm{pH}$ was adjusted to the desired level using $0.5 \mathrm{M} \mathrm{H}_{2} \mathrm{SO}_{4}$ or $0.5 \mathrm{M} \mathrm{NaOH}$ solutions, and a specific catalyst dose (when used) was added. Ozone was then continuously bubbled into the vessel through two air diffusers at a rate of $0.063 \mathrm{~m}^{3} \mathrm{~h}^{-1}$. The reactor was operated in semi-batch mode for 6 h. Samples withdrawn at regular intervals were filtered through a PVDF membrane (Millipore; $0.22 \mu \mathrm{m}$ pore size) for the analytical determination of the TOC, 1,4-dioxane concentration [1,4-dioxane], aqueous ozone concentration $\left[\mathrm{O}_{3}\right], \mathrm{pH}$ and acute toxicity. 
In previous tests performed to select a suitable catalyst, involving a comparison of the TOC removal and ozone decomposition rate obtained using different non-noble metals (goethite, cerium oxide or copper oxide), copper oxide resulted in the highest catalytic activity $[28,37]$.

\section{Ozone decomposition experiments}

The same reactor described above was used to determine the rate of ozone decomposition. The experiments were carried out using $1.5 \mathrm{~L}$ of deionized water in the absence of catalyst and in the presence of the $\mathrm{CuO}$ catalyst at $0.1 \mathrm{ppm}, 0.25 \mathrm{ppm}$ or 0.5 ppm. Ozone was then continuously bubbled into the reactor at a rate of $0.063 \mathrm{~m}^{3} \mathrm{~h}^{-1}$, at $25 \pm 1{ }^{\circ} \mathrm{C}$ and at $\mathrm{pH} 10,7.0,5.5$ or 3.0 . Samples collected at appropriate intervals over a period of $40 \mathrm{~min}$ were rapidly filtered through a PVDF membrane (Millipore; $0.22 \mu \mathrm{m}$ pore size). The residual aqueous ozone concentration (C) was evaluated in a spectrophotometer (HACH DR 5000) by quantifying the absorbance at $258 \mathrm{~nm}$ by the Lambert-Beer law (Eq. 1).

$$
\mathrm{ABS}=\varepsilon \mathrm{LC}
$$

where $\varepsilon$ is the molar extinction coefficient equal to $2950 \mathrm{M}^{-1} \mathrm{~cm}^{-1}$ at $258 \mathrm{~nm}$ [36], $\mathrm{L}$ is the optical path and $\mathrm{C}$ is the ozone concentration in the aqueous phase.

The theoretical aqueous ozone concentration was calculated through the liquid phase mass balance (Eq. 2):

$$
\begin{aligned}
& \frac{\mathrm{dC}_{O_{3}}}{\mathrm{dt}}=\mathrm{k}_{\mathrm{L}_{\mathrm{a}}}\left(\mathrm{C}_{\mathrm{sat}}-\mathrm{C}_{\mathrm{O}_{3}}\right)-\mathrm{k}_{\mathrm{T}} \mathrm{C}_{\mathrm{O}_{3}} \\
& \mathrm{k}_{\mathrm{T}}=\mathrm{k}_{\mathrm{d}}+\mathrm{wk}_{\text {het }}
\end{aligned}
$$


where $\mathrm{C}_{\mathrm{sat}}$ is the saturated ozone concentration, $\mathrm{C}_{\mathrm{O} 3}$ the aqueous ozone concentration, $\mathrm{k}_{\mathrm{L}}$ the volumetric mass transfer coefficient, $\mathrm{k}_{\mathrm{T}}$ the ozone decomposition rate constant, $\mathrm{k}_{\mathrm{d}}$ the ozone self-decomposition constant, w the catalyst dosage and khet the catalytic ozone decomposition constant. The right-hand side of Eq. 2 reduces to a pseudo-first-order rate law under an excess of ozone in the reactor.

The ozone self-decomposition constant $\left(\mathrm{k}_{\mathrm{d}}\right)$ was obtained through the correlation proposed by Sullivan [38] (Eq. 4).

$$
\mathrm{k}_{\mathrm{d}}=9.811 \cdot 10^{7}\left[\mathrm{OH}^{-}\right]^{0.123} \exp \left(\frac{-5606}{\mathrm{~T}}\right)
$$

where $\left[\mathrm{OH}^{-}\right]$is the $\mathrm{OH}^{-}$concentration and $\mathrm{T}$ is the temperature in Kelvin.

\section{Catalyst reuse}

The catalyst was reused in selected experiments to assess its stability over multiple cycles. At the end of each cycle, the catalyst was separated by membrane filtration (Millipore; $0.22 \mu \mathrm{m}$ pore size). The solids were dried at $60 \pm 1{ }^{\circ} \mathrm{C}$ for $15 \mathrm{~h}$ and reused for the subsequent cycle without any further purification.

\section{Analytical methods}

The $\mathrm{pH}$ was determined by the potentiometric method using a $\mathrm{pH}$ meter (Quimis, Model Q400A), previously calibrated with $\mathrm{pH} 4.0$ and 7.0 buffer solutions. The concentration of leached copper ion in the liquid phase after the heterogeneous catalytic ozonation reactions was measured using AAS.

The aqueous ozone concentration during the experiments was analyzed as described in section 2.4 and the TOC was determined on a TOC- $\mathrm{V}_{\mathrm{CPH}}$ analyzer (Shimadzu). 
The 1,4-dioxane was extracted according to the methodology proposed by $\mathrm{Li}$ and collaborators [39] and quantified using a CG-MS instrument (Shimadzu QP2010 plus) equipped with a Supel-Q PLOT column. The column temperature was maintained at 150 ${ }^{\circ} \mathrm{C}$ during the analysis (total time was $4 \mathrm{~min}$ ) and the injector and interface temperature was $200^{\circ} \mathrm{C}$. Samples $(1 \mu \mathrm{L})$ were injected in split mode $(1: 18)$. Helium was used as the carrier gas. The quantification and confirmation ions were $\mathrm{m} / \mathrm{z} 88$ and $\mathrm{m} / \mathrm{z} 58$, respectively.

The 1,4-dioxane and TOC degradation rate constants $\left(\mathrm{k}_{1}\right)$ were obtained according to the pseudo-first-order rate laws (Eq. 5) together with the material balance of the batch reactor, which was operated under an excess of ozone (continuous bubbling).

$$
-\ln \left(\frac{\mathrm{C}}{\mathrm{C}_{0}}\right)=\mathrm{k}_{1} t
$$

where $\mathrm{C}_{0}$ and $\mathrm{C}$ are the initial concentration and the concentration after the catalytic ozonation process at various time intervals, respectively, $\mathrm{k}_{1}$ is either the 1,4 -dioxane or TOC degradation pseudo-first-order rate constant $\left(\mathrm{min}^{-1}\right)$ and $t$ is the reaction time. The first-order rate constant $\left(\mathrm{k}_{1}\right)$ was determined by the slope of the straight line fitting of $\ln \left(\mathrm{C} / \mathrm{C}_{0}\right)$ versus time.

The acute toxicity test with the bioluminescent bacteria Vibrio fischeri (lyophilized) was performed according to the methodology proposed by ISO 11348-3 $[40]$.

\section{Results and Discussion}

\section{Catalyst characterization}

The morphology of the $\mathrm{CuO}$ powder is shown in the TEM images in Figure 1. The $\mathrm{CuO}$ particles had irregular spherical shapes with different diameters and were well 
distributed without aggregation [41,42]. The XRD pattern for $\mathrm{CuO}$, with lattice planes of vibration, can be seen in Figure 1b (JCPDS 48-1548). The XRD analysis showed a series of diffraction peaks at $2 \theta=32.4^{\circ}, 35.6^{\circ}, 38.8^{\circ}, 48.9^{\circ}, 53.3^{\circ}, 58.2^{\circ}, 61.6^{\circ}, 66.3^{\circ}$ and $67.9^{\circ}$ characteristic of the monoclinic phase of copper (II) oxide [43].

[Figure 1 near here]

The results for the main parameters used to characterize the $\mathrm{CuO}$ particles are shown in Table 1. High purity and low surface area are notable features of the catalyst used in this study.

[Table 1 near here]

The oxidation state of the $\mathrm{CuO}$ before and after the catalytic ozonation of 1,4dioxane was investigated by XPS (Figure 2). The $\mathrm{O} 1 \mathrm{~s}$ spectra for the $\mathrm{CuO}$ after and before catalytic ozonation can be seen in Figures $2 \mathrm{a}$ and $2 \mathrm{~b}$, respectively. The peaks at 528.97$529.21 \mathrm{eV}$ were attributed to lattice oxygen and the peaks at 530.76-531.10 eV were assigned to O-C, as well as to the oxygen adsorbed at the surface $[44,45]$. The smallest peak, observed only for the sample before catalytic ozonation at $533.17 \mathrm{eV}$, was assigned to $\mathrm{O}-\mathrm{H}$ and/or to oxygen adsorbed at the surface $[44,46]$.

Figures $2 \mathrm{c}$ and $2 \mathrm{~d}$ show the two doublets $\mathrm{Cu}-2 \mathrm{p}_{3 / 2}$ and $\mathrm{Cu}-2 \mathrm{p}_{1 / 2}$, presenting energetic differences of $20 \mathrm{eV}$, in good agreement with data published in the literature [46]. In general, copper oxide can exist in two phases, cupric oxide $(\mathrm{CuO})$ and cuprous oxide $\left(\mathrm{Cu}_{2} \mathrm{O}\right)$. The peaks at $934.2 \mathrm{eV}$ and $954.2 \mathrm{eV}$ are attributed to $\mathrm{CuO}\left(\mathrm{Cu}^{2+}\right)$. However, the peaks at $932.2 \mathrm{eV}$ and $952.2 \mathrm{eV}$ are attributed to $\mathrm{Cu}_{2} \mathrm{O}\left(\mathrm{Cu}^{+}\right)$, indicating the presence of $\mathrm{Cu}_{2} \mathrm{O}$ on the solid surface of the sample caused by redox reactions on the solid surface [47]. The satellite peaks in the spectra $(941.7 \mathrm{eV}, 943.05 \mathrm{eV}$ and $961.7 \mathrm{eV})$ are associated with the presence of $\mathrm{Cu}(\mathrm{II})(\mathrm{CuO})[45,46]$. Since no $\mathrm{Cu}_{2} \mathrm{O}$ diffractions peaks were detected in the XRD pattern (Fig. 1b), this is restricted to the surface. 
For the $\mathrm{CuO}$ sample after catalytic ozonation the peaks at $934.2 \mathrm{eV}$ and $954.2 \mathrm{eV}$ shifted to lower binding energy when compared to the sample before the reaction, which means that more $\mathrm{Cu}^{+}$was present on the $\mathrm{CuO}$ surface after ozonation.

[Figure 2 near here]

\section{Catalytic decomposition of ozone}

The impact of $\mathrm{CuO}$ on the absorption and decomposition of ozone was determined at different $\mathrm{pH}$ values and using different catalyst dosages at $\mathrm{pH} 5.5$ (Figure S1). Table 2 shows the $\mathrm{k}_{\mathrm{d}}, \mathrm{C}_{\mathrm{e}}$ and khet values, determined by fitting Eq. 2 to the experimental results. The values of $\mathrm{k}_{\mathrm{La}}\left(0.475 \pm 0.036 \mathrm{~min}^{-1}\right)$ and $\mathrm{C}_{\text {sat }}(10.264 \pm 1.063 \mathrm{ppm})$ were constant and dependent only on the reaction temperature $\left(25^{\circ} \mathrm{C}\right)$ and the mixing conditions in the reactor. The residual concentration of ozone at equilibrium $\left(\mathrm{C}_{\mathrm{e}}\right)$ showed a small decrease as the $\mathrm{pH}$ increased, in the absence of catalyst, since ozone was continuously supplied into the system. In contrast, the ozone decomposition constant $\left(\mathrm{k}_{\mathrm{d}}\right)$ rapidly increased above $\mathrm{pH} 7$ due to the decomposition of $\mathrm{O}_{3}$ molecules to ${ }^{\circ} \mathrm{OH}$ radicals [48]. The catalytic ozone decomposition constant ( $\mathrm{k}_{\text {het }}$ ) decreased slightly as the catalyst dose was increased, remaining close to the average value of $1.268 \pm 0.018$. The mechanism of heterogeneous catalytic ozone decomposition, as proposed by Beltrán et al. [48], is described in Eqs. 6 -9 .

$$
\begin{aligned}
& \mathrm{OH}^{-}+\mathrm{S} \leftrightarrow \mathrm{OH} \cdot \mathrm{S} \\
& \mathrm{O}_{3}+\mathrm{OH} \cdot \mathrm{S} \leftrightarrow \mathrm{O}_{3} \cdot \mathrm{S}+\mathrm{HO} \\
& \mathrm{O}_{3} \cdot \mathrm{S} \leftrightarrow \mathrm{O} \cdot \mathrm{S}+\mathrm{O}_{2} \\
& \mathrm{O}_{3}+\mathrm{O} \cdot \mathrm{S} \leftrightarrow \mathrm{O}_{2}+\mathrm{S}+\mathrm{O}_{2}
\end{aligned}
$$


where $\mathrm{S}$ is the catalyst surface. The above reactions are the steps involved in the surface chemical reaction involving adsorption, surface reaction and desorption processes.

[Table 2 near here]

\section{Degradation and mineralization of 1,4-dioxane by ozone in the absence of catalyst}

The chromatographic analysis showed that 1,4-dioxane could be efficiently removed from the water with ozone alone under alkaline conditions (Figure 3). In contrast, at $\mathrm{pH} \leq 7$ the rate of degradation was very low. No mineralization was observed under acidic or basic $\mathrm{pH}$, since the $\mathrm{pH}$ rapidly decreased during the reaction (Figure $\mathrm{S} 2$ ).

Lower $\mathrm{pH}$ values do not favor the decomposition of $\mathrm{O}_{3}$ to ${ }^{\circ} \mathrm{OH}$, which has a much greater reactivity with 1,4-dioxane than $\mathrm{O}_{3}[49,50]$. This chain mechanism of ${ }^{\circ} \mathrm{OH}$ production is initiated by hydroxide anions at higher $\mathrm{pH}$ values, where the reaction proceeds through the conversion of ${ }^{\bullet} \mathrm{O}_{3}{ }^{-}$to ${ }^{\bullet} \mathrm{OH}[13]$. The lower reactivity of 1,4 -dioxane with molecular $\mathrm{O}_{3}$ at $\mathrm{pH} \leq 7$ results from the absence of significantly electron-rich sites in the molecular structure of 1,4-dioxane.

[Figure 3 near here]

The pseudo-first-order kinetics constant was obtained from Eq. 5, since the reactor was operated under an excess of ozone. The rate constants of 1,4-dioxane removal $\left(\mathrm{k}_{1}\right)$ at pH 3.0, 5.5 and 7.0 were quite similar $\left(0.00061 \pm 0.00007 \mathrm{~min}^{-1}, 0.00071 \pm 0.00007 \mathrm{~min}^{-1}\right.$, $0.00065 \pm 0.00004 \mathrm{~min}^{-1}$ respectively). In contrast, at $\mathrm{pH} 10$ a significantly higher value was reached $\left(0.00249 \pm 0.00008 \mathrm{~min}^{-1}\right)$. Barndõk and collaborators [13] determined significantly higher pseudo-first-order rate constants for 1,4-dioxane degradation, under an excess of ozone, at $\mathrm{pH} 7.0$ and $10.0\left(1.2 \mathrm{~min}^{-1}\right.$ and $30 \mathrm{~min}^{-1}$, respectively). The faster kinetics may have resulted from the use of constant $\mathrm{pH}$ throughout the experiment and a significantly higher ozone flow rate $\left(0.24 \mathrm{~m}^{3} \mathrm{~h}^{-1}\right)$. 
However, the rate constants for the decomposition of ozone over the $\mathrm{CuO}$ catalyst $\left(k_{\text {het }}\right.$, Table 2) were at least 3 orders of magnitude higher than that for the reaction of ozone with 1,4-dioxane at $\mathrm{pH} 5.5\left(0.00071 \pm 0.00007 \mathrm{~min}^{-1}\right)$. As a consequence, in the presence of $\mathrm{CuO}$, the degradation of 1,4-dioxane by direct ozonation alone is slow in comparison to the reaction between 1,4-dioxane and the free radicals produced by the ozone decomposition on the solid surface at $\mathrm{pH} 5.5$.

\section{Catalyzed ozonation of 1,4-dioxane with $\mathrm{CuO}$}

In heterogeneous catalytic ozonation, the role of the $\mathrm{pH}$ involves multiple aspects, including the decomposition of the ozone molecules, the surface properties of the catalyst and the charge of ionizable organic molecules, which in turn affects the production of reactive oxygen species (ROS) and the degradation rate of water contaminants [24,25]. The effect of the initial $\mathrm{pH}$ on 1,4-dioxane degradation and mineralization under catalytic ozonation was investigated using $250 \mathrm{ppm}$ of $\mathrm{CuO}$. The results in Figures $\mathrm{S} 2 \mathrm{a}$ and S2b show that the rate of TOC and 1,4-dioxane removal increased slightly as the $\mathrm{pH}$ increased and the rate of degradation was considerably higher at $\mathrm{pH} 10$. The relatively small impact of the initial $\mathrm{pH}$ observed in these unbuffered experiments can be attributed to the relatively fast decrease in the $\mathrm{pH}$, which reached a plateau at similar $\mathrm{pH}$ values (around 5 to 6) (Figure S2c).

The concentration profiles for ozone in the aqueous phase observed during the experimental runs can be seen in Figure 4a. The concentration of ozone in the absence and in the presence of $\mathrm{CuO}$ rapidly increased during the initial stage of the reaction, reaching equilibrium concentrations $\left(\mathrm{C}_{\mathrm{e}}\right)$ approaching the saturation values, observed in the absence of 1,4-dioxane at the temperature of the experiments (Table 2). These results 
demonstrate that the gas-liquid ozonation reactions occurred through a relatively slow kinetic regime (small Hatta numbers) [51].

[Figure 4 near here]

The pseudo-first-order rate constants of ozonation and $\mathrm{CuO}$ catalytic ozonation of 1,4-dioxane as a function of $\mathrm{pH}$ are shown in Figures $4 \mathrm{~b}$ (mineralization) and $4 \mathrm{c}$ (degradation). The $\mathrm{k}_{1}$ value for catalytic ozonation at $\mathrm{pH} 7$, with $250 \mathrm{ppm}$ of $\mathrm{CuO}$, increased by factors of 22.3 and 3.12 for TOC and 1,4-dioxane removal, respectively, in comparison to ozonation. The increase in the TOC removal with an initial $\mathrm{pH}$ of 10 is not significant, especially in the absence of $\mathrm{CuO}$, due to the decrease in the $\mathrm{pH}$ during the reactions. It is known that the ozone decomposition with the formation of hydroxyl radicals is greatly enhanced under highly alkaline conditions [27]. However, the pH decreased during the reaction and reached a value of 4 after $6 \mathrm{~h}$. The $\mathrm{k}_{1}$ value at $\mathrm{pH} 3$ increased by factors of $\mathrm{xxx}$ and $\mathrm{zzz}$ for TOC and 1,5 dioxane removal, respectively in comparison to ozonation. It is expected that homogeneous catalytic ozonation also could occur due to leaching of copper ions, that increased from $0.1 \%, 0.3 \%$ to $4.9 \%$ at the initial $\mathrm{pH}$ of 7.0, 5.5 and 3.0, respectively. Although the homogeneous catalytic ozonation can not be neglected at the initial $\mathrm{pH} 3$ due to copper leaching as $\mathrm{Cu}^{2+}$ ions, at $\mathrm{pH}$ circumneutral the main reactions responsible to 1,4-dioxane degradation occur as a heterogeneous catalytic process.

Conversely, a significant impact on the rate of TOC and 1,4-dioxane removal (Figure S3) was observed as the concentration of $\mathrm{CuO}$ was increased from 100 to $3000 \mathrm{ppm}$, at neutral $\mathrm{pH}$. 
The pseudo-first-order kinetics constants at different catalyst concentrations are reported in Figure 5b. It can be observed that the rate constants $\left(\mathrm{k}_{1}\right)$ increased by factors of 81.25 and 10.35 for TOC and 1,4-dioxane removal, respectively, at $\mathrm{pH} 7$ with 3000 ppm of $\mathrm{CuO}$. These values suggest that 1,4-dioxane and TOC removal are strongly dependent on the amount of catalyst used, in agreement with results reported in the literature for other target water contaminants $[20,52,26]$.

An increase in the catalyst surface area and the amount of active sites available favored the decomposition of ozone, as shown by the lower equilibrium concentrations of ozone in solution (Figure 5a). The subsequent enhanced production of ROS and the reaction with 1,4-dioxane and its breakdown products led to higher rates of mineralization $[20,52]$.

In the absence of ozone, 1,4-dioxane would be removed by adsorption onto the solid surface, because the formation of free radicals at room temperature is negligible [53]. In fact, $\mathrm{CuO}$ is an effective catalyst for the degradation of organic compounds by wet catalytic oxidation via a radical reaction mechanism [54], but these reactions only occur at high temperature $\left(200-325^{\circ} \mathrm{C}\right)$ and pressure $(5-15 \mathrm{MPa})$ in the presence of oxygen/air [55].

The impact of the adsorption of 1,4-dioxane by $\mathrm{CuO}$ can be considered negligible, since only $4 \%$ of the TOC and $8 \%$ of the 1,4-dioxane was adsorbed by $3000 \mathrm{ppm}$ of $\mathrm{CuO}$ after $6 \mathrm{~h}$ (Figure S4). The low adsorption capacity of $\mathrm{CuO}$ is due to its low specific area (Table 1), the high solubility of 1,4-dioxane in water and low pressure, which also results in insignificant removal by adsorption on activated carbon [13].

The results collectively show that the effect of catalytic ozonation in the presence of $\mathrm{CuO}$ was higher than the combined effect of adsorption onto the catalyst surface and 
ozonation in the absence of catalyst, demonstrating that $\mathrm{CuO}$ is a highly active ozonation catalyst for the mineralization of 1,4-dioxane.

[Figure 5 near here]

\section{Radical species and reaction mechanism}

The nature of the ROS produced during the $\mathrm{CuO}$ catalytic ozonation reaction was investigated in the presence of selected radical scavengers: salicylic acid (SA), sodium fluoride (NaF), 1,4-benzoquinone (PBQ) and phosphate (PHOS). The results in Figure 6 show the pseudo-first-order rate constant for the 1,4-dioxane and TOC removal. The TOC was evaluated for reactions with $\mathrm{NaF}$ and PHOS because these scavengers had no influence on the TOC detection.

SA and $\mathrm{NaF}$ were used to determine the role of ${ }^{\circ} \mathrm{OH}_{\text {free }}$ and ${ }^{\circ} \mathrm{OH}_{\text {ads }}$, respectively, in the degradation of 1,4-dioxane, $[48,49]$. Although tert-butanol (TBA) is generally used as an ${ }^{\circ} \mathrm{OH}$ scavenger this was not employed in this study since the second-order reaction rate of TBA with ${ }^{\circ} \mathrm{OH}\left(5.0 \times 10^{8} \mathrm{M}^{-1} \mathrm{~s}^{-1},[56]\right)$ was slower than the reaction rate of 1,4dioxane with ${ }^{\circ} \mathrm{OH}\left((1.1\right.$ to 2.35$) \times 10^{9} \mathrm{M}^{-1} \mathrm{~s}^{-1}$, [57]). On the other hand, SA reacts faster with ${ }^{\circ} \mathrm{OH}$, with a reaction rate of $2.2 \times 10^{10} \mathrm{M}^{-1} \mathrm{~s}^{-1}[58]$.

The reaction rate in the presence of SA decreased only slightly (by a factor of 1.2), indicating that ${ }^{\circ} \mathrm{OH}$ free had a negligible effect on the 1,4-dioxane degradation. In the presence of $\mathrm{NaF}$, the reaction rate decreased by factors of 1.4 and 1.7 for 1,4-dioxane and TOC, respectively, suggesting that ${ }^{\circ} \mathrm{OH}_{\text {ads }}$ had a stronger influence in the degradation of the intermediate products. In contrast, in the presence of PBQ, a superoxide radical $\left(\mathrm{O}_{2}{ }^{-}\right.$ -) scavenger $[59,60]$, the reaction rate decreased by a factor of 2.7 , indicating that $1,4-$ dioxane was mainly degraded by $\mathrm{O}_{2}^{-\bullet}$.

Lewis acid sites are considered to be catalytic centers on the catalyst surface for ozone decomposition reactions $[32,61]$. On the other hand, PHOS has high affinity toward 
the Lewis acids and thus can fill the active sites on the surface of catalysts, leading to a loss of catalytic activity. Figure 6 shows that in the presence of PHOS the reaction rate decreased by factors of 7.52 and 1.32 for TOC and 1,4-dioxane removal, respectively, suggesting that the adsorption of ozone on the catalyst surface was prevented. This effect was more significant for the degradation of the intermediate products compared with the removal of 1,4-dioxane.

\section{[Figure 6 near here]}

The reaction intermediates detected by GC-MS in the experiment using $3000 \mathrm{ppm}$ of $\mathrm{CuO}$ at $\mathrm{pH} 7$ were investigated to elucidate further the degradation of 1,4-dioxane by ozone alone and by catalytic ozonation. Similar intermediates were detected in the two cases; however, the appearance of the primary intermediates was faster and more pronounced in the presence of $\mathrm{CuO}$. Ethylene glycol, formic acid and succinic acid were identified as the major reaction intermediates and the evolution of their concentrations in the presence of $\mathrm{CuO}$ can be seen in Fig. S5.

A simplified reaction scheme for 1,4-dioxane decomposition by catalytic ozonation with $\mathrm{CuO}$ is given in Figure 7. The presence of ethylene glycol (EG) and formic acid (FA) as reaction intermediates, suggested that the degradation pathway mainly progressed through the formation of ethylene glycol diformate (EGDF) [62,63], although this compound was not detected by GC-MS as it quickly hydrolyzes to EG [13] and FA [64]. It should be noted that EG has previously been reported as the main intermediate of 1,4-dioxane during ozonation [13], electrolysis/ $\mathrm{O}_{3}[65]$, Fenton [63] and $\mathrm{UV} / \mathrm{H}_{2} \mathrm{O}_{2} / \mathrm{Fe}^{0}$ [62] treatments.

[Figure 7 near here]

\section{Catalyst stability and reusability}


The recyclability and stability of the catalyst are critical factors for the large-scale application of heterogeneous catalytic ozonation systems for water and wastewater treatment. In this study, the recyclability and stability of the $\mathrm{CuO}$ used in the treatment of 1,4-dioxane by catalyst ozonation were assessed during five consecutive reuse cycles.

The catalytic activity of $\mathrm{CuO}$ during each cycle decreased slightly (Figure $8 \mathrm{a}$ ) but remained at acceptable values. The TOC and 1,4-dioxane removal efficiencies decreased from $49 \%$ to $30 \%$ and from $78 \%$ to $56 \%$, respectively, but were still significantly higher than the removals achieved with ozonation alone $(20 \%$ for 1,4 -dioxane and negligible for TOC). The apparent loss of activity could result from the poisoning of the active sites, fouling of the catalyst surface by the reaction products, the loss of catalyst mass during each reusing cycle and copper leaching [20,21].

The FTIR spectra for the $\mathrm{CuO}$ before and after five cycles of catalytic ozonation (Figure $8 \mathrm{~b}$ ) show no alterations, suggesting good stability and structural composition of the catalyst. A strong absorption band peak was observed at $539 \mathrm{~cm}^{-1}$ due to the vibrational stretching of $\mathrm{CuO}$ [63]. The peaks observed in the range of $1107 \mathrm{~cm}^{-1}$ and $1637 \mathrm{~cm}^{-1}$ may be attributed to $\mathrm{O}-\mathrm{H}$ bending vibrations combined with copper atoms. The presence of humid air and hydrated $\mathrm{CuO}$ samples was responsible for the formation of peaks in the range of 2900 and $3500 \mathrm{~cm}^{-1}$ [67].

Copper leaching from the catalyst to the solution during catalytic ozonation at $\mathrm{pH}$ 7 was quantified after each cycle by AAS. Copper leaching was 0.28 ppm, 0.26 ppm, 0.2 ppm, $0.12 \mathrm{ppm}$ and $0.7 \mathrm{ppm}$ for cycles $1,2,3,4$ and 5 , respectively. The sum of the amount of copper dissolved in the aqueous media during all cycles was less than $0.1 \%$, indicating that the $\mathrm{CuO}$ catalyst has a high degree of stability.

[Figure 8 near here]

\section{Acute toxicity test with Vibrio fischeri}


The toxicity results for the water containing 1,4-dioxane, before and after treatment in the absence and presence of $\mathrm{CuO}(3000 \mathrm{ppm})$, after 0, 30, 60 and $360 \mathrm{~min}$, are shown in Fig. 9. The acute toxicity observed after the treatment in the presence of $\mathrm{CuO}$ was significantly lower than that observed after the treatment in the absence of the catalysis. Catalytic oxidation with $\mathrm{CuO}$ increased the mineralization rate of the toxic intermediates formed during the 1,4-dioxane oxidation treatment, as also observed in the case of treatment by the photoelectron-peroxone process [68]. Notably, the toxicity of the samples treated by ozonation alone increased significantly during the treatment process, presumably due to the insignificant rate of mineralization observed, suggesting a gradual accumulation of toxic intermediates in solution, in agreement with the results obtained using the electro-peroxone process [69]. This observation indicates that detailed toxicity studies need to be performed before implementing advanced water treatment processes.

[Figure 9 near here]

\section{Conclusions}

This study demonstrated the effective treatment of 1,4-dioxane by catalytic ozonation using $\mathrm{CuO}$. It was found that the mechanism of reaction involves primarily superoxide radicals, rather than hydroxyl radicals. These in turn react with 1,4-dioxane to form ethylene glycol, which was further decomposed to formic acid with a higher rate of mineralization when compared with ozonation alone. This further contributed to reducing the acute toxicity of the treated water. In contrast, in the absence of catalyst the toxicity of the water increased after treatment by ozonation at circumneutral $\mathrm{pH}$.

\section{Acknowledgements}


The authors would like to acknowledge CAPES/Brazil (Coordination for the Improvement of Higher Education Personnel) for scholarships, CNPq/Brazil (Brazilian Council for Scientific and Technological Development) for financial support (grant number 405892/2013 6), LCME (Central Laboratory of Electronic Microscopy) for the MET analysis and Édipo Silva for zeta potential measurements. Partial funding was provided by the NSF Engineering Research Center on Nanotechnology-Enabled Water Treatment (EEC-1449500). 


\section{References}

[1] Weimar R. Prevent groundwater contamination before it's too late. Water Wastes Eng. 1980;17:30-33.

[2] Abe A. Distribution of 1,4-dioxane in relation to possible sources in the water environment. Sci Total Environ. 1999; 227(1):41-47.

[3] USEPA. Treatment Technologies for 1,4-Dioxane: Fundamentals and Field Applications, EPA-542-R-06-009. Office of Solid Waste and Emergency Response. Washington (DC): USEPA, 2006.

[4] Mohr TKG. Environmental Investigation and Remediation: 1,4-Dioxane and Other Solvent Stabilizers. CRC Press:2010.

[5] Barndõk H, Hermosilla D, Negro C, et al. Comparison and Predesign Cost Assessment of Different Advanced Oxidation Processes for the Treatment of 1,4Dioxane-Containing Wastewater from the Chemical Industry. ACS Sustain Chem Eng. 2018;6(5):5888-5894.

[6] ECB. E.U. risk assessment report: 1,4-dioxane, ISBN 92-894-1252-6, Second Priority List 21. Office for Official Publications of the European Communities. Luxembourg: 2002:1-129.

[7] USEPA. Toxicological review of 1,4-dioxane (CAS No. 123-91-1), EPA/635/R09/005-F. Washington (DC): USEPA, 2010.

[8] Kim HS, Kwon BH, Yoa SJ, et al. Degradation of 1,4-dioxane by photo-Fenton processes. J. Chem. Eng. Jpn.2008;41:829-835.

[9] So MH, Han JS, Han TH, et al. Decomposition of 1,4-dioxane by photo-Fenton oxidation coupled with activated sludge in a polyester manufacturing process. Water Sci. Technol. 2009;59:1003-1009.

[10] Li M, Mathieu J, Liu Y, et al. The Abundance of Tetrahydrofuran/Dioxane Monooxygenase Genes (thmA/dxmA) and 1,4-Dioxane Degradation Activity Are Significantly Correlated at Various Impacted Aquifers. ES\&T Letters. 2014;1:122-127. [11] Vescovi T, Coleman HM, Amal R. The effect of $\mathrm{pH}$ on UV-based advanced oxidation technologies-1,4-dioxane degradation. J. Hazard. Mater. 2010;182:75-79.

[12] Kiker JH, Connolly JB, Murray WA, et al. Ex-situ wellhead treatment of 1,4-dioxane using Fenton's reagent. Proc. Annu. Int. Conf. Soils, Sediments, Water Energy. 2010;15:210-226. 
[13] Barndõk H, Cortijo L, Hermosilla D, et al. Removal of 1,4-dioxane from industrial wastewaters: Routes of decomposition under different operational conditions to determine the ozone oxidation capacity. J. Hazard. Mat. 2014;280:340-347.

[14] Eberle D, Ball R, Boving TB. Peroxone activated persulfate treatment of 1,4-dioxane in the presence of chlorinated solvent co-contaminants. Chemosphere. 2016;144:728735 .

[15] Wang H, Bakheet B, Yuan S, et al. Kinetics and energy efficiency for the degradation of 1,4-dioxane by electro-peroxone process. J. Hazard. Mater. 2015;294:90-98.

[16] Adams CD, Scanlan PA, Secrist ND. Oxidation and biodegradability enhancement of 1,4-dioxane using hydrogen peroxide and ozone. Environ. Sci. Technol. 1994;28:18121818.

[17] Suh JH, Mohseni M. A study on the relationship between biodegradability enhancement and oxidation of 1,4-dioxane using ozone and hydrogen peroxide. Water Res. 2004;38:2596-2604.

[18] Chitra S, Paramasivan K, Cheralathan M. Degradation of 1,4-dioxane using advanced processes. Environ. Sci. Pollut. Res. 2012;19:871-878.

[19] Kwon SC, Kim JY, Yoon SM, et al. Treatment characteristic of 1,4-dioxane by ozone-based advanced oxidation processes. J. Ind. Eng. Chem. 2012;18:1951-1955.

[20] Ahmadi M, Kakavandi B, Jaafarzadeh N, et al. Catalytic ozonation of high saline petrochemical wastewater using $\mathrm{PAC} @ \mathrm{FeIIFe}_{2} \mathrm{IIIO}_{4}$ : Optimization, mechanisms and biodegradability studies. Sep. Purif. Technol. 2017;177:293-303.

[21] Vakilabadi DR, Hassani AH, Omrani G, et al. Catalytic potential of $\mathrm{Cu} / \mathrm{Mg} / \mathrm{Al}-$ chitosan for ozonation of real landfill leachate. Process Saf. Environ. 2017;107:227-237. [22] Sable SS, Ghute PP, Fakhrnasova D, et al. Catalytic ozonation of clofibric acid over copper-based catalysts: In situ ATR-IR studies. Appl. Catal. B- Environ. 2017;209:523529.

[23] Ziylan-Yavaş A, Ince NH. Catalytic ozonation of paracetamol using commercial and Pt-supported nanocomposites of $\mathrm{Al}_{2} \mathrm{O}_{3}$ : The impact of ultrasound. Ultrason Sonochem. 2018;40(B):175-182.

[24] Chen W, Li X, Pan Z, et al. Effective mineralization of Diclofenac by catalytic ozonation using Fe-MCM-41 catalyst. Chem. Eng. J. 2016;304:594-601.

[25] Huang Y, Cui C, Zhang D, et al. Heterogeneous catalytic ozonation of dibutyl phthalate in aqueous solution in the presence of iron-loaded activated carbon. Chemosphere. 2015;119:295-301. 
[26] Chen C, Chen H, Guo X, et al. Advanced ozone treatment of heavy oil refining wastewater by activated carbon supported iron oxide. J. Ind. Eng. Chem. 2014;20:27822791.

[27] Zhang T, Li W, Croué J-P. A non-acid-assisted and non-hydroxyl-radical-related catalytic ozonation with ceria supported copper oxide in efficient oxalate degradation in water. Appl. Catal. B-Environ. 2012;121-122:88-94.

[28] Centurião APSL, Baldissarelli V, Scaratti G, Amorim SM de, Moreira RFPM. Enhanced ozonation degradation of petroleum refinery wastewater in the presence of oxide. Environ. Technol. DOI: 10.1080/09593330.2017.1420103

[29] Tian GP, Wu QY, Li A, et al. Promoted ozonation for the decomposition of 1,4dioxane by activated carbon. Water Sci. Technol. Water Supply. 2016;17(2):613-620.

[30] Zhang J, Huang G-Q, Liu C, et al. Synergistic effect of microbubbles and activated carbon on the ozonation treatment of synthetic dyeing wastewater. Sep. Purif. Technol. 2018;201:10-18.

[31] Xiong Z, Lai B, Yuan Y, et al. Degradation of p-nitrophenol (PNP) in aqueous solution by a micro-size $\mathrm{Fe}^{0} / \mathrm{O}_{3}$ process $\left(\mathrm{mFe}^{0} / \mathrm{O}_{3}\right)$ : Optimization, kinetic, performance and mechanism. Chem. Eng. J. 2016;302:137-145.

[32] Kasprzyk-Hordern B, Ziólek M, Nawrocki J. Catalytic ozonation and methods of enhancing molecular ozone reactions in water treatment. Appl. Catal. B-Environ. 2003;46:639-669.

[33] Gharbani P, Mehrizad A. Heterogeneous catalytic ozonation process for removal of 4-chloro-2-nitrophenol from aqueous solutions. J. Saudi Chem. Soc. 2014;18:601-605.

[34] $\mathrm{Hu} \mathrm{E}, \mathrm{Wu} \mathrm{X}$, Shang S, et al. Catalytic ozonation of simulated textile dyeing wastewater using mesoporous carbon aerogel supported copper oxide catalyst. J. Clean. Prod. 2016;112:4710-4718.

[35] Von GU. Ozonation of drinking water: Part I. Oxidation kinetics and product formation. Water Res. 2003;37:1443-1467.

[36] APHA. Standard methods for the examination of water and wastewater. 19th ed., Washington DC: APHA; 1995.

[37] Scaratti G. Removal of 1,4-dioxane from industrial wastewaters: Routes of decomposition using catalytic ozonation or peroxidation coupled to membrane filtration (Qualifying exam - Dissertation). Florianopolis (Brazil): Federal University of Santa Catarina; 2017. 
[38] Sullivan DE, Roth JA. Kinetics of ozone self-decomposition in aqueous solution. AlChe Symp Series. 1979;79:142-149.

[39] Li M, Conlon P, Fiorenza S, et al. Rapid analysis of 1,4-dioxane in Groundwater by Frozen Micro-Extraction with Gas Chromatography/Mass Spectrometry. Ground Water Monit. R. 2011;31:70-76.

[40] ISO 11348-3. Water quality - determination of the inhibitory effect of water samples on the light emission of Vibrio fischeri (Luminescent bacteria test), Part 3: Method using freeze-dried bacteria. Geneva: International Organization for Standardization 2007.

[41] Xu L, Srinivasakannan C, Peng J, et al. Synthesis of $\mathrm{Cu}-\mathrm{CuO}$ nanocomposite in microreactor and its application to photocatalytic degradation. J. Alloys Compd. 2017;695:263-269.

[42] Raj ASA, Biju V. Nanostructured CuO: Facile synthesis, optical absorption and defect dependent electrical conductivity. Mat. Sci. Semicon. 2017;68:38-47.

[43] Ananth A, Dharaneedharan S, Heo M-S, et al. Copper oxide nanomaterials: Synthesis, characterization and structure-specific antibacterial performance. Chem. Eng. J. 2015;262:179-188.

[44] Lupan O, Cretu V, Postica V, et al. Enhanced ethanol vapour sensing performances of copper oxide nanocrystals with mixed phases. Sensor. Actuat. B-Chem. 2016;224:434448.

[45] Zhou L-J, Zou Y-C, Zhao J, et al. Facile synthesis of highly stable and porous $\mathrm{CuO} / \mathrm{CuO}$ cubes with enhanced gas sensing properties. Sensor. Actuat. B-Chem. 2013;188:533-539.

[46] Shen Y, Guo M, Xia X, et al. Role of materials chemistry on the electrical/electronic properties of $\mathrm{CuO}$ thin films. Acta Mater. 2015;85:122-131.

[47] Huang L, Zheng M, Yu D, et al. In-situ fabrication and catalytic performance of Co$\mathrm{Mn} @ \mathrm{CuO}$ core-shell nanowires on copper meshes/foams, Materials \& Design, Volume 147, 2018, Pages 182-190.

[48] Beltrán FJ. Ozone Reaction Kinetics for Water and Wastewater Systems, 1st ed. Spain: Lewis Publishers, 2004.

[49] Kwon SC, Kim JY, Yoon SM, et al. Treatment characteristic of 1,4-dioxane by ozone-based advanced oxidation processes. J. Ind. Eng. Chem. 2012;18:1951-1955.

[50] Suh JH, Mohseni M. A study on the relationship between biodegradability enhancement and oxidation of 1,4-dioxane using ozone and hydrogen peroxide. Water Res. 2004;38:2596-2604. 
[51] Lan BY, Nigmatullin R, Li Puma G. Ozonation kinetic of cork-processing water in a bubble column reactor. Water Res. 2008;42:2473-2482.

[52] Huang Y, Sun Y, Xu Z, et al. Removal of aqueous oxalic acid by heterogeneous catalytic ozonation with $\mathrm{MnO} /$ sewage sludge-derived activated carbon as catalysts. Sci. Total Environ. 2017;575:50-57.

[53] Ji F, Li C, Deng L. Performance of CuO/Oxone system: Heterogeneous catalytic oxidation of phenol at ambient conditions. Chem. Eng. J. 2011, 178:239-243.

[54] Sadana A, Katzer JR. Involvement of free radicals in the aqueous-phase catalytic oxidation of phenol over copper oxide. J. Catal. 1974, 35:140-152.

[55] Sushma, Kumari M, Saroha, AK. Performance of various catalysts on treatment of refractory pollutants in industrial wastewater by catalytic wet air oxidation: A review. J. Environ. Manage. 2018, 228:169-188.

[56] Hoigné J, Bader H. Rate constants of reactions of ozone with organic and inorganic compounds in water-II. Water Res. 1983;17:185-194.

[57] Thomas JK. Rates of reaction of the hydroxyl radical. Trans. Faraday Soc. 1965;61:702-707.

[58] Crittenden JC, Trussel RR, Hand DW, et al. Water Treatment: Principles and Design, John Wiley \& Sons, 2012.

[59] Nawaz F, Xie Y, Cao H, et al. Catalytic ozonation of 4-nitrophenol over an mesoporous $\alpha-\mathrm{MnO}$ with resistance to leaching. Catal. Today. 2015;258:595-601.

[60] Yang M-Q, Zhang Y, Zhang N, et al. Visible-light-driven oxidation of primary C-H bonds over CdS with dual co-catalysts graphene and TiO2. Sci. Rep. 2013;3:3314.

[61] Mashayekh-Saehi A, Moussavi G, Yaghmaeian K. Preparation, characterization and catalytic activity of a novel mesoporous nanocrystalline $\mathrm{MgO}$ nanoparticle for ozonation of acetaminophen as an emerging water contaminant. Chem. Eng. J. 2017;310:157-169.

[62] Barndõk H, Blanco L, Hermosilla D, et al. Heterogeneous photo-Fenton processes using zero valent iron microspheres for the treatment of wastewaters contaminated with 1,4-dioxane. Chem. Eng. J. 2016;284:112-121.

[63] Merayo N, Hermosilla D, Cortijo L, et al. Optimization of the Fenton treatment of 1,4-dioxane and on-line FTIR monitoring of the reaction. J. Hazard. Mat. 2014;268:102109.

[64] Vollhardt KPC, Schore NE. Organic Chemistry: Structure and Function. 6th ed. W.H. Freeman and Co. 2011. 
[65] Kishimoto N. Dependeny of Advanced Oxidation Performance on the Contaminated Water Feed Mode for Ozonation Combined with Electrolysis Using a Two-compartment Electrolytic Flow-Cell. J. Adv. Oxi. Technol.2015;10:241-246.

[66] Bhuvaneshwari S, Gopalakrishnan N. Hydrothermally synthesized Copper Oxide (CuO) superstructures for ammonia sensing. J. Colloid Interf. Sci. 2016;480:76-84.

[67] Dubal DP, Dhawale DS, Salunkhe RR, et al. Fabrication of copper oxide multilayer nanosheets for supercapacitor application. J. Alloys Compd. 2010;492:26-30.

[68] Shen W, Wang Y, Zhan J, et al. Kinetics and operational parameter for 1,4-dioxane degradation by the photoelectron-peroxone process. Chem. Eng. J. 2017;310:249-258.

[69] Wang H, Bakheet B, Yuan S, et al. Kinetics and energy efficiency for the degradation of 1,4-dioxane by electro-peroxone process. J. Hazard. Mater. 2015;294:90-98. 
Table 1: Characterization of $\mathrm{CuO}$ particles.

\begin{tabular}{c|c}
\hline Particle Size, $\mathbf{n m}$ & $77-200$. \\
Purity, $\%$ & $100 \%$ \\
Point of zero charge & 7.41 \\
BET surface area, $\mathbf{~ m}^{\mathbf{2}} \mathbf{g}$ & 12.61 \\
Pore size diameter, $\mathbf{n m}$ & $3.6 \mathrm{~nm}$ \\
Total pore volume, $\mathbf{c m}^{\mathbf{3}} \mathbf{g}^{-1}$ & 0.044 \\
\hline
\end{tabular}


Table 2: The $\mathrm{k}_{\mathrm{d}}$, Ce and $\mathrm{k}_{\mathrm{het}}$ values for deionized water ozonation at different $\mathrm{pH}$ values and catalyst dosages $\left(\mathrm{k}_{\mathrm{La}}=0.475 \pm 0.036 \mathrm{~min}^{-1}\right.$ and $\left.\mathrm{C}_{\mathrm{sat}}=10.264 \pm 1.063 \mathrm{ppm}\right)$ (ozone flow rate $\left.=0.064 \mathrm{~m}^{3} \mathrm{~h}^{-1} ; \mathrm{T}=25 \pm 1{ }^{\circ} \mathrm{C}\right)$.

\begin{tabular}{c|ccc}
\hline $\mathbf{C u O}$ dosage/pH & $\mathbf{k d}\left(\mathbf{m i n}^{-\mathbf{1}}\right)$ & $\mathbf{C e}(\mathbf{p p m})$ & $\mathbf{k h e t}\left(\mathbf{m i n}^{\mathbf{- 1}}\right)$ \\
\hline $0 \mathrm{ppm} / 10.0$ & 0.21 & $7.87 \pm 0.03$ & - \\
$0 \mathrm{ppm} / 7.0$ & 0.09 & $8.18 \pm 0.16$ & - \\
$0 \mathrm{ppm} / 5.5$ & 0.06 & $8.75 \pm 0.06$ & - \\
$0 \mathrm{ppm} / 3.0$ & 0.03 & $9.16 \pm 0.17$ & - \\
$0.1 \mathrm{ppm} / 5.5$ & 0.06 & $4.31 \pm 0.01$ & $1.34 \pm 0.01$ \\
$0.25 \mathrm{ppm} / 5.5$ & 0.06 & $4.21 \pm 0.01$ & $1.26 \pm 0.02$ \\
$0.5 \mathrm{ppm} / 5.5$ & 0.06 & $4.02 \pm 0.01$ & $1.20 \pm 0.02$ \\
\hline
\end{tabular}


(a)

(b)
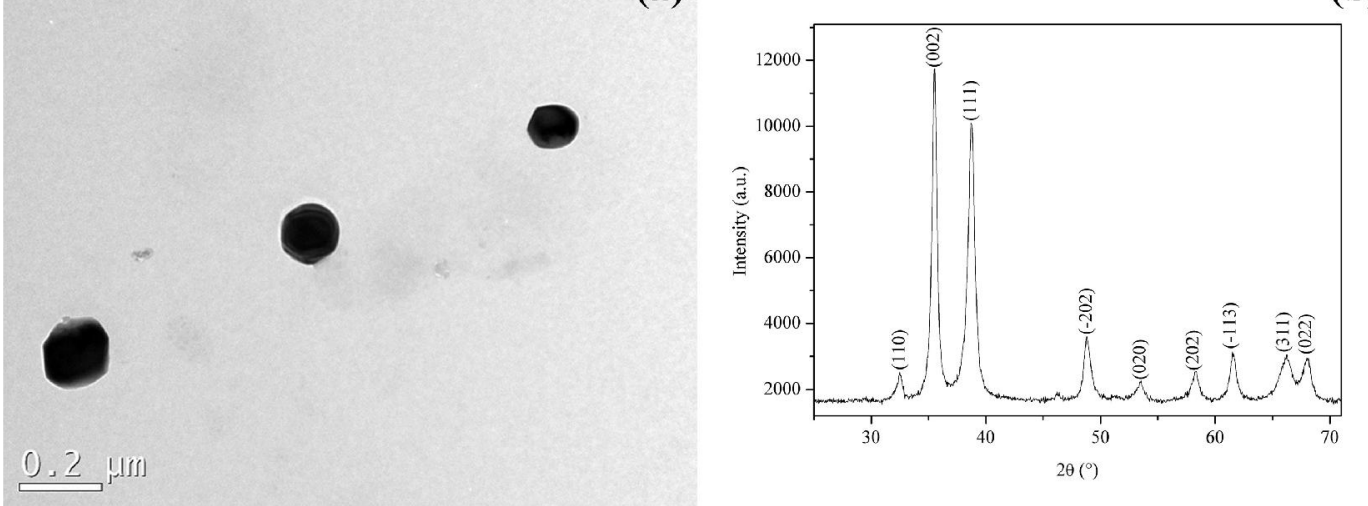

Figure 1: (a) TEM images of $\mathrm{CuO}$ and (b) XRD of $\mathrm{CuO}$. 

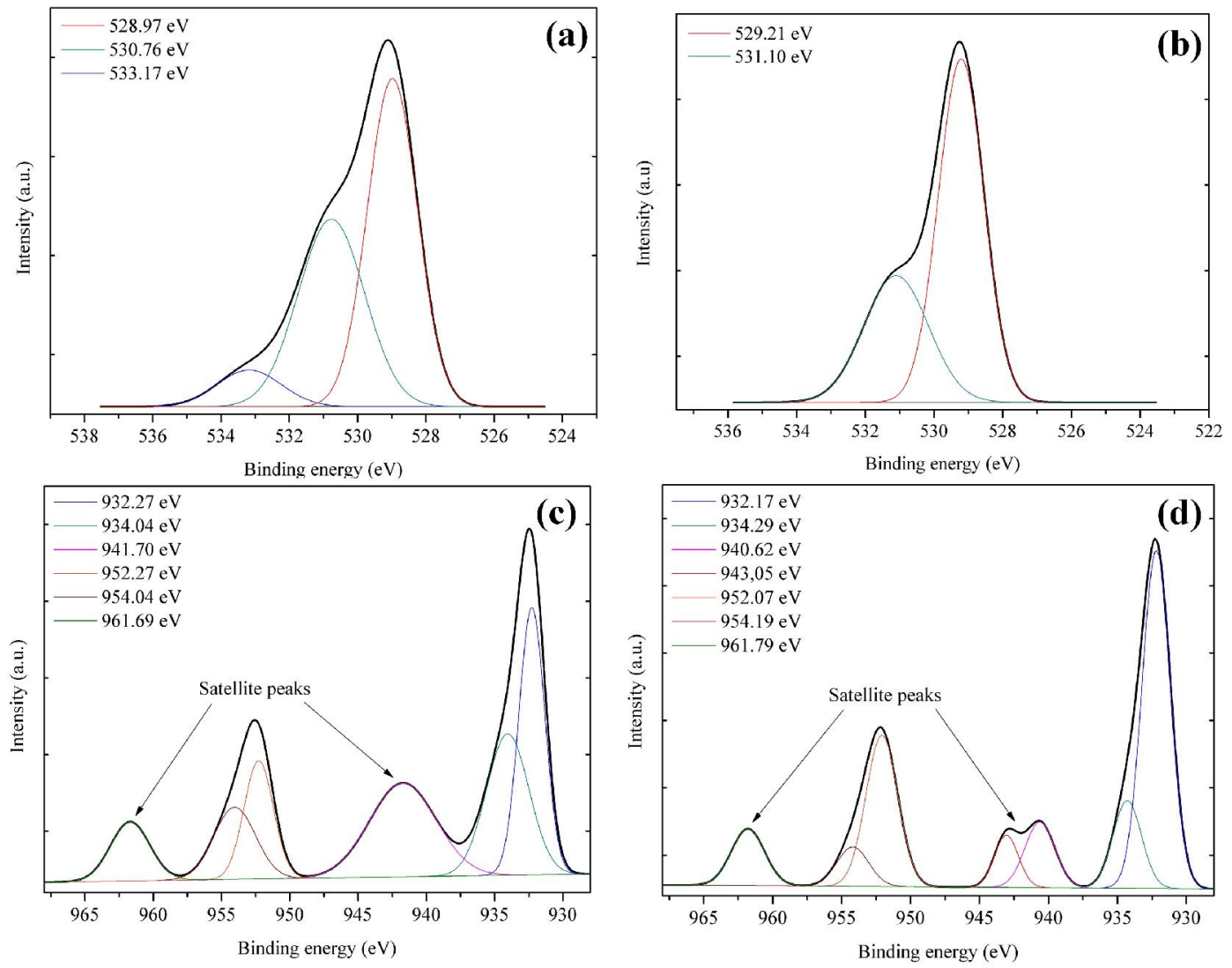

Figure 2: XPS spectra: (a, c) $\mathrm{CuO}$ before catalytic ozonation and (b, d) $\mathrm{CuO}$ after catalytic ozonation (ozone flow $=0.064 \mathrm{~m}^{3} \mathrm{~h}^{-1} ; \mathrm{T}=25 \pm 1^{\circ} \mathrm{C}$ ). 


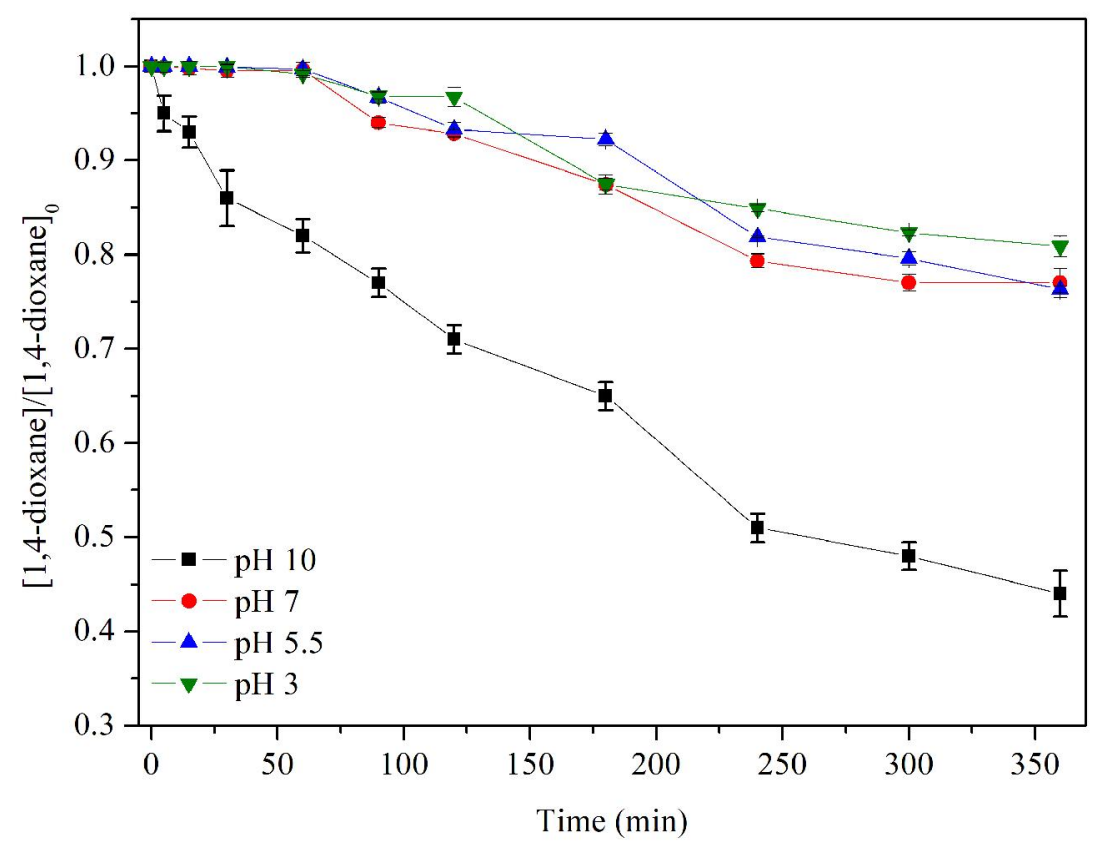

Figure 3: Kinetics of 1,4-dioxane removal at different $\mathrm{pH}$ values $([1,4$-dioxane $]=200$ ppm; ozone flow $=0.064 \mathrm{~m}^{3} \mathrm{~h}^{-1} ; \mathrm{T}=25 \pm 1{ }^{\circ} \mathrm{C}$ ). 

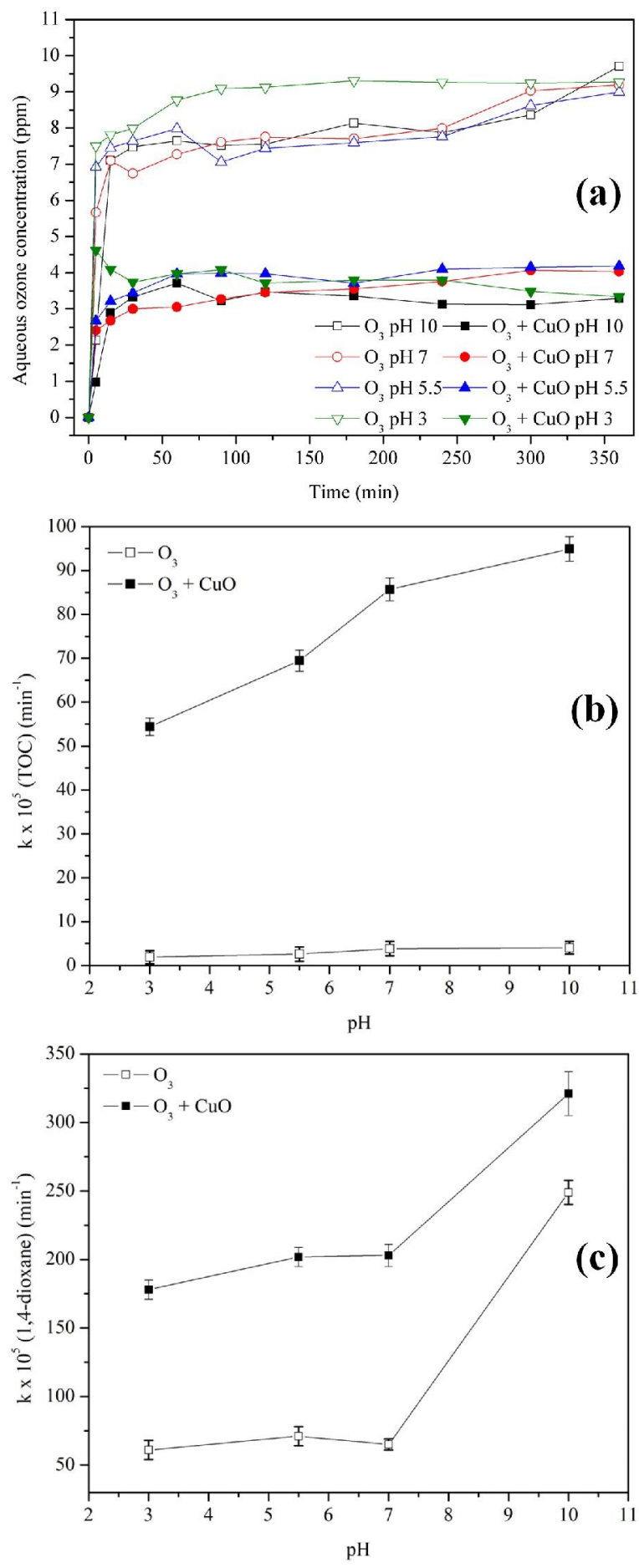

Figure 4: (a) Aqueous ozone concentration in the absence and presence of $\mathrm{CuO}$, (b) pseudo-first order constants for 1,4-dioxane and (c) pseudo-first-order constants for TOC at different initial $\mathrm{pH}$ values during 1,4-dioxane catalytic ozonation $([\mathrm{CuO}]=250 \mathrm{ppm}$; $[1,4$-dioxane $]=200 \mathrm{ppm} ;$ ozone flow $\left.=0.064 \mathrm{~m}^{3} \mathrm{~h}^{-1} ; \mathrm{T}=25 \pm 1^{\circ} \mathrm{C} ; \mathrm{t}=360 \mathrm{~min}\right)$. 

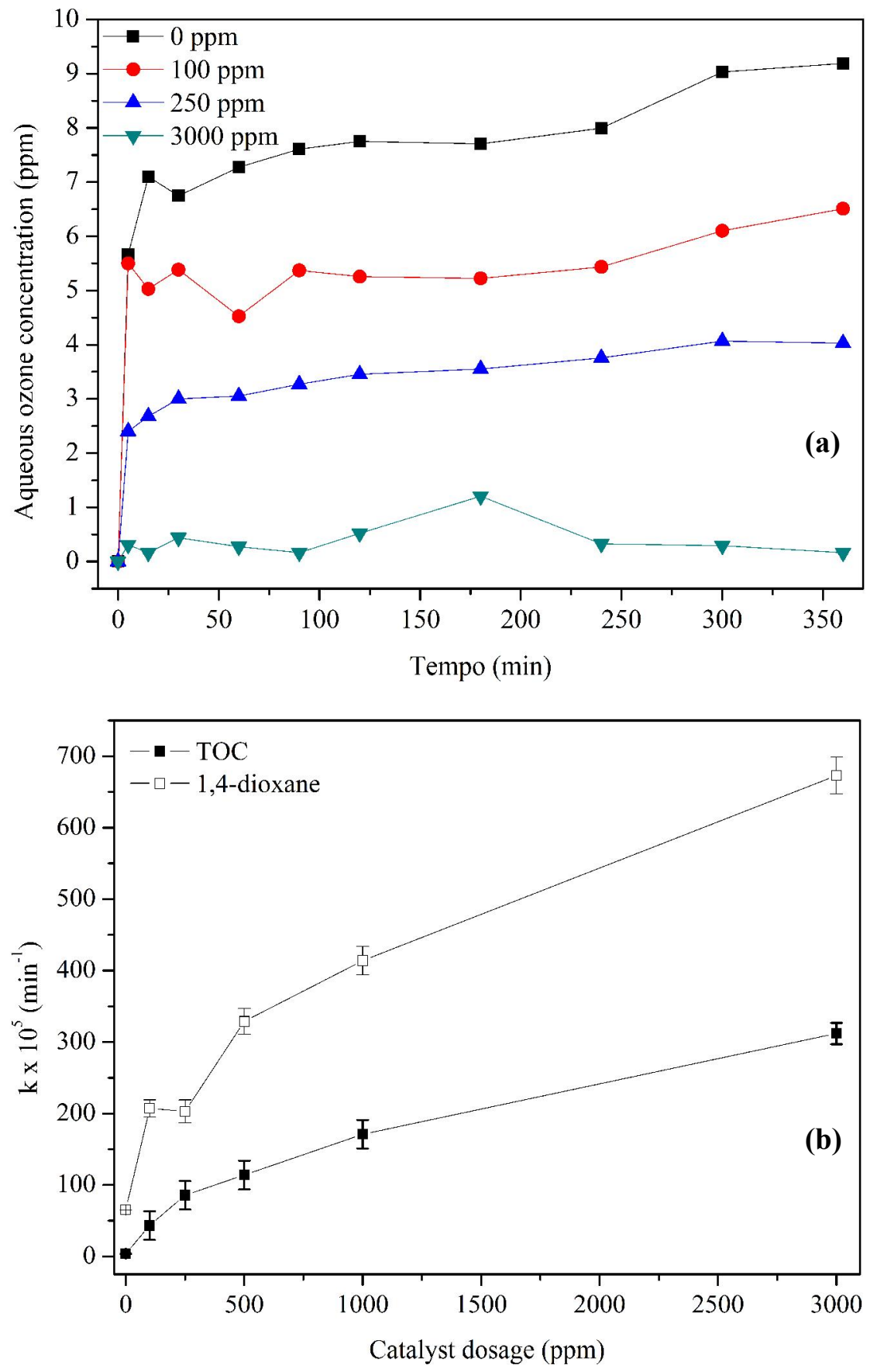

Figure 5: (a) Aqueous ozone concentrations with different catalyst dosages; (b) Pseudofirst-order constants for 1,4-dioxane and TOC removal after $6 \mathrm{~h}$ of reaction at different dosages of $\mathrm{CuO}\left([1,4\right.$-dioxane $]=200 \mathrm{ppm} ; \mathrm{pH}=7.0 \pm 0.5$; ozone flow $=0.064 \mathrm{~m}^{3} \mathrm{~h}^{-1} ; \mathrm{T}$ $\left.=25 \pm 1{ }^{\circ} \mathrm{C}\right)$. 


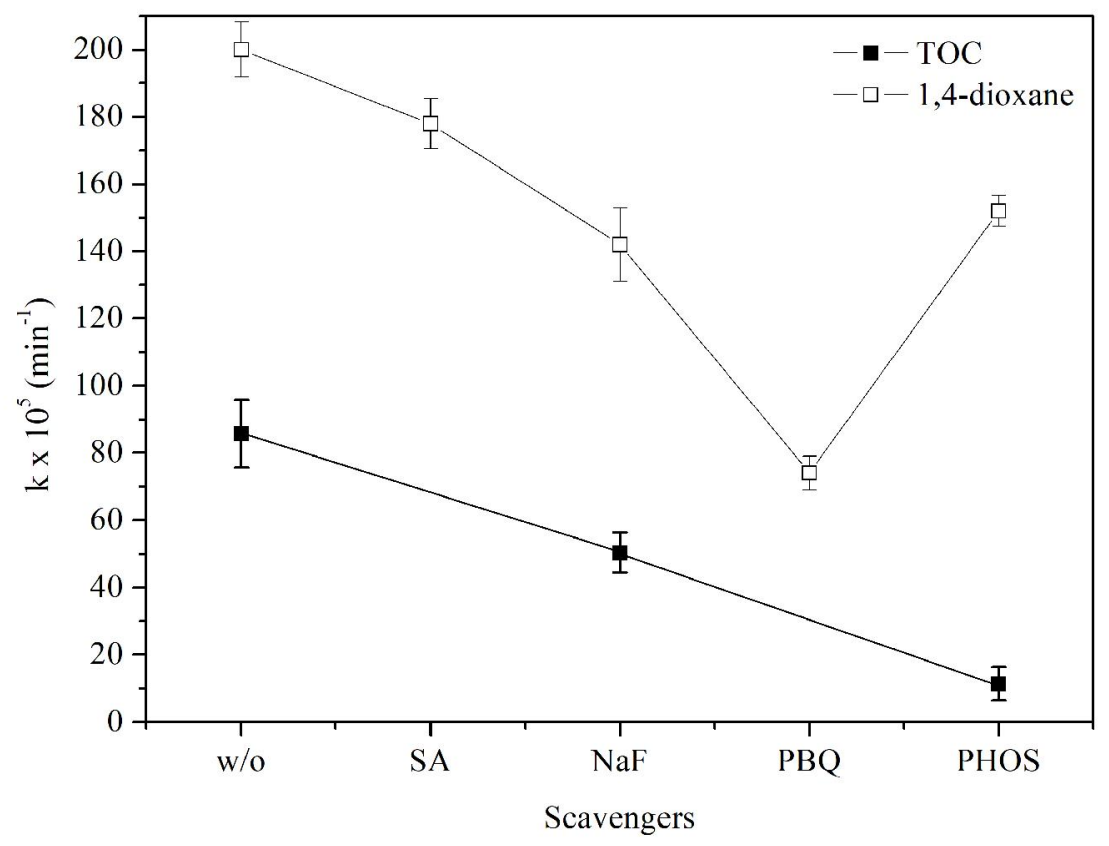

Figure 6: Pseudo-first-order constants for 1,4-dioxane and TOC removal after $6 \mathrm{~h}$ of reaction in the presence of selected radical scavengers $([1,4$-dioxane $]=200 \mathrm{ppm} ;[\mathrm{CuO}]$ $=250$ ppm; $\mathrm{pH}=7.0 \pm 0.5 ;$ ozone flow $=0.064 \mathrm{~m}^{3} \mathrm{~h}^{-1} ; \mathrm{T}=25 \pm 1{ }^{\circ} \mathrm{C} ;[\mathrm{SA}]$ and $[\mathrm{PBQ}]=$ $10 \mathrm{mM} ;[\mathrm{NaF}]=60 \mathrm{mM} ;[\mathrm{PHOS}]=40 \mathrm{mM})$.

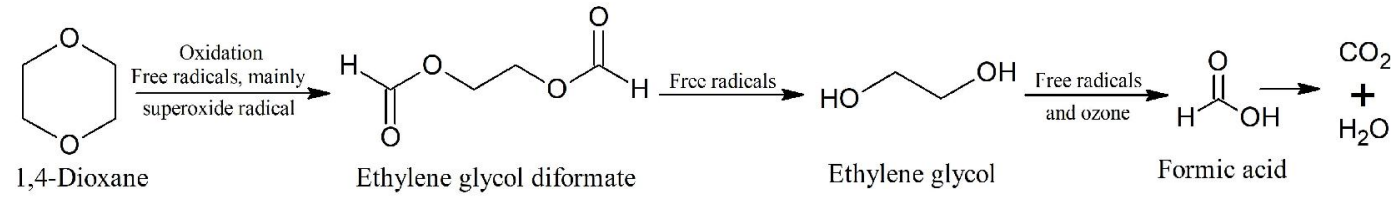

Figure 7: Simplified schematic of 1,4-dioxane decomposition by catalytic ozonation with $\mathrm{CuO}([1,4-$ dioxane $]=200 \mathrm{ppm},[\mathrm{CuO}]=3000 \mathrm{ppm}, \mathrm{pH}=7.0 \pm 0.5$, ozone flow $=0.064$ $\mathrm{m}^{3} \mathrm{~h}^{-1}$ and $\left.\mathrm{T}=25 \pm 1{ }^{\circ} \mathrm{C}\right)$. 

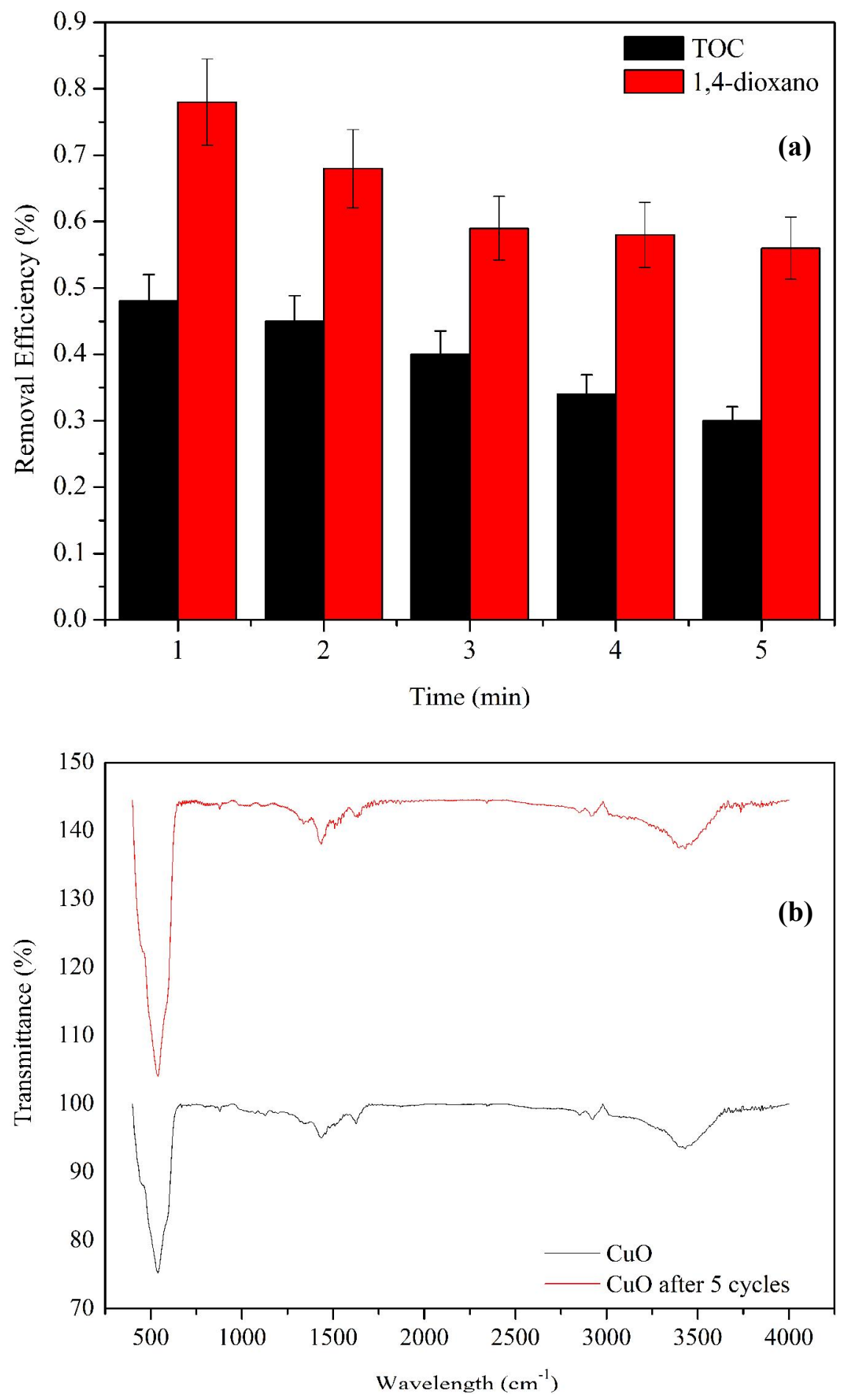

Figure 8: (a) The stability and reusability of $\mathrm{CuO}$ in the catalytic ozonation of 1,4-dioxane over 5 cycles and (b) FTIR spectra of $\mathrm{CuO}$ before and after 5 cycles of catalytic ozonation $\left([1,4\right.$-dioxane $]=200 \mathrm{ppm} ; \mathrm{pH}=7.0 ;$ ozone flow $=0.064 \mathrm{~m}^{3} \mathrm{~h}^{-1} ; \mathrm{T}=25 \pm 1{ }^{\circ} \mathrm{C} ;$ [catalyst $]$ $=1000$ ppm; reaction time: $360 \mathrm{~min}$ ). 


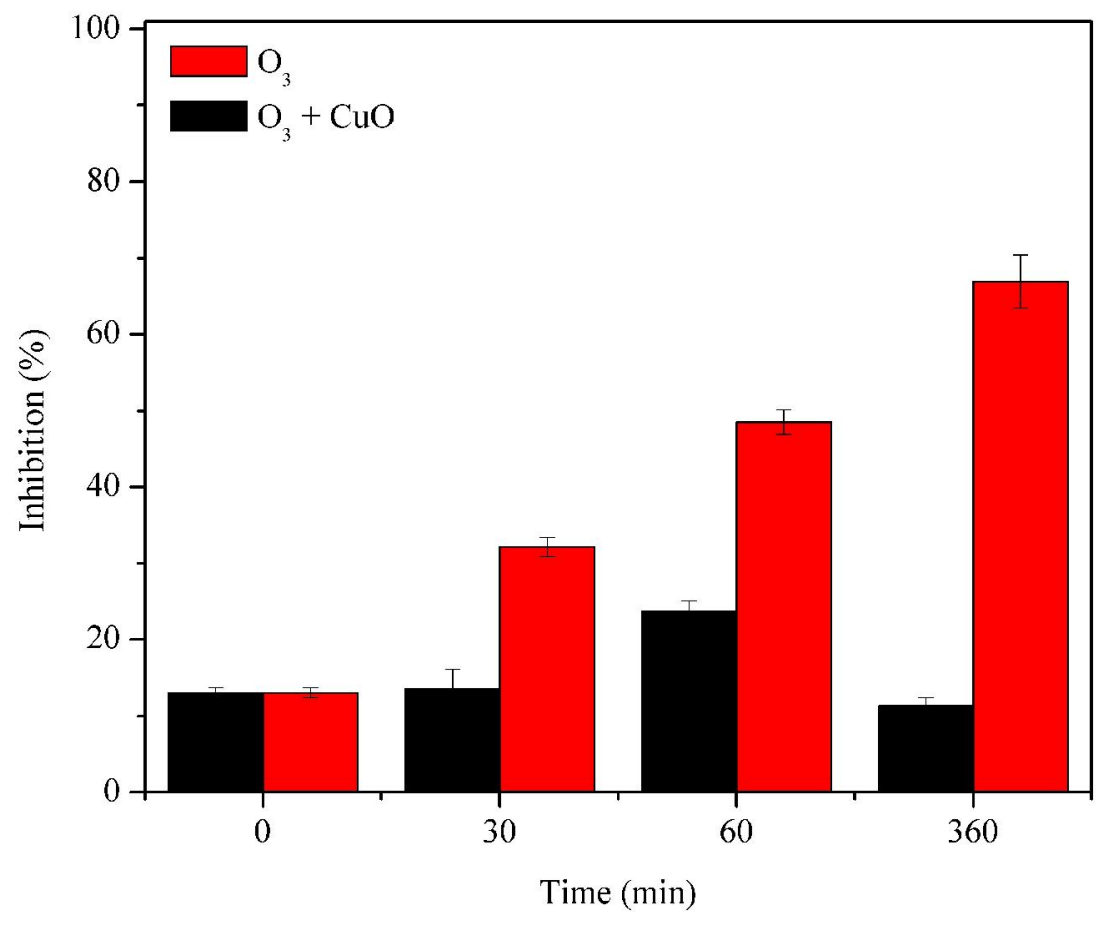

Figure 9: Acute toxicity of 1,4-dioxane and byproducts after ozonation or catalytic ozonation for $0,30,60$ and $360 \min ([1,4-$ dioxane $]=200 \mathrm{ppm} ; \mathrm{pH}=7.0$; ozone flow $=$ $0.064 \mathrm{~m}^{3} \mathrm{~h}^{-1} ; \mathrm{T}=25 \pm 1{ }^{\circ} \mathrm{C}$; [catalyst $]=3000 \mathrm{ppm}$; reaction time: $360 \mathrm{~min}$ ). 


\title{
TREATMENT OF AQUEOUS SOLUTIONS OF 1,4-DIOXANE BY OZONATION AND CATALYTIC OZONATION WITH COPPER OXIDE (CuO)
}

\author{
SCARATTI, G. ${ }^{1 *}$; BASSO, A. ${ }^{1}$; LANDERS, R. ${ }^{2}$; ALVAREZ, P. ${ }^{3} ;$ LI PUMA, G ${ }^{4}$; \\ MOREIRA, R. F. P. M. ${ }^{1}$
}
${ }^{1}$ Department of Chemical and Food Engineering, Federal University of Santa Catarina, Florianópolis, SC, Brazil
${ }^{2}$ Institute of Physics Gleb Wataghin, University of Campinas, Campinas, SP, Brazil
${ }^{3}$ Department of Civil and Environmental Engineering, Rice University, Houston, TX, USA
${ }^{4}$ Environmental Nanocatalysis \& Photoreaction Engineering, Department of Chemical Engineering, Loughborough University, Loughborough, United Kingdom

*Corresponding author: Tel: +55 4837216441

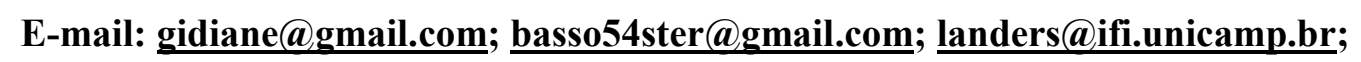
alvarez@rice.edu; g.lipuma@lboro.ac.uk; regina.moreira@ufsc.br 

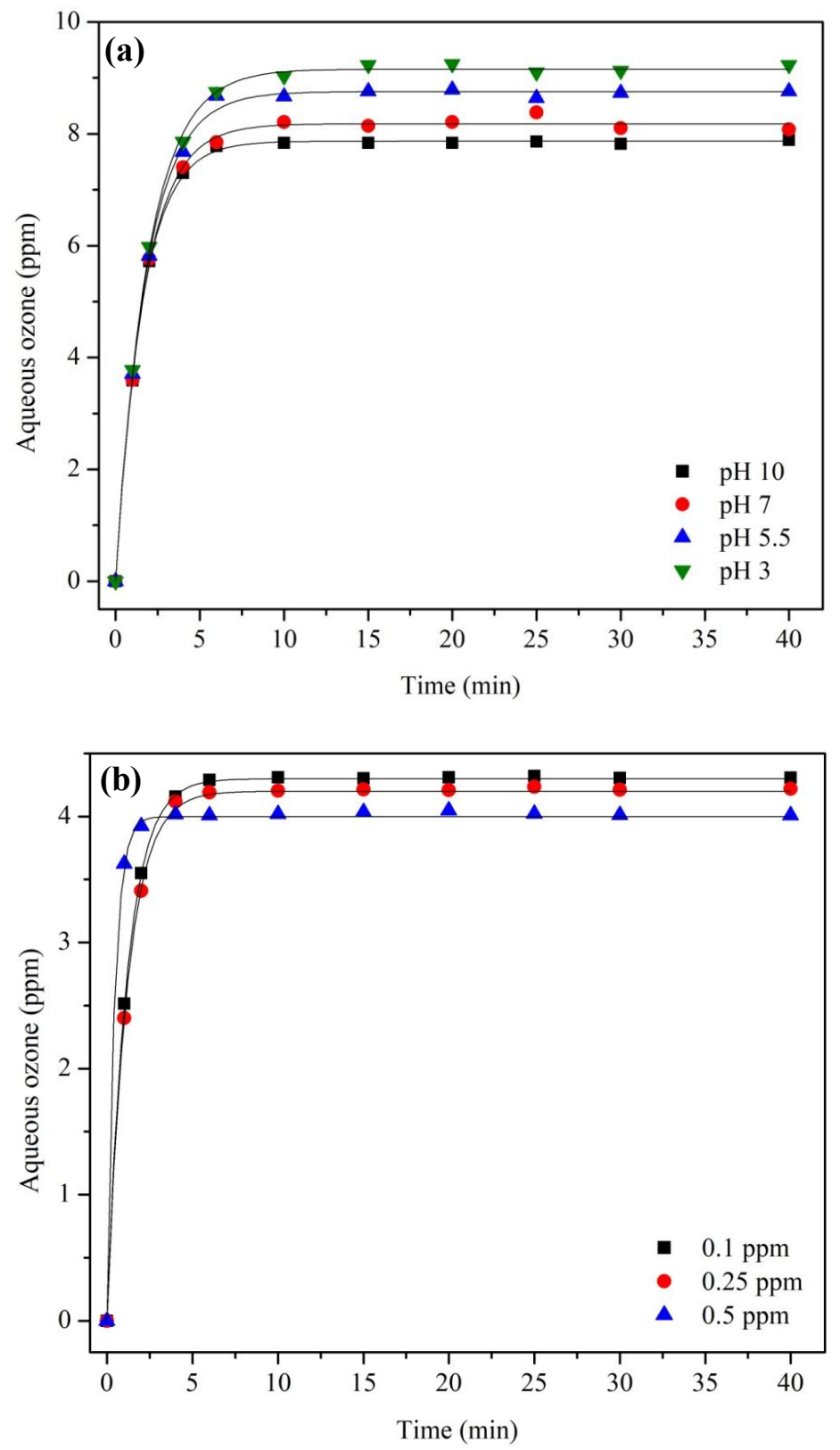

Figure S1: Effect of (a) $\mathrm{pH}$ and (b) catalyst dosage at $\mathrm{pH} 5.5$ on the ozone absorption and catalytic ozone decomposition $\left(\mathrm{pH}=5.5\right.$; ozone flow $\left.=0.064 \mathrm{~m}^{3} \mathrm{~h}^{-1} ; \mathrm{T}=25 \pm 1^{\circ} \mathrm{C}\right)$. 

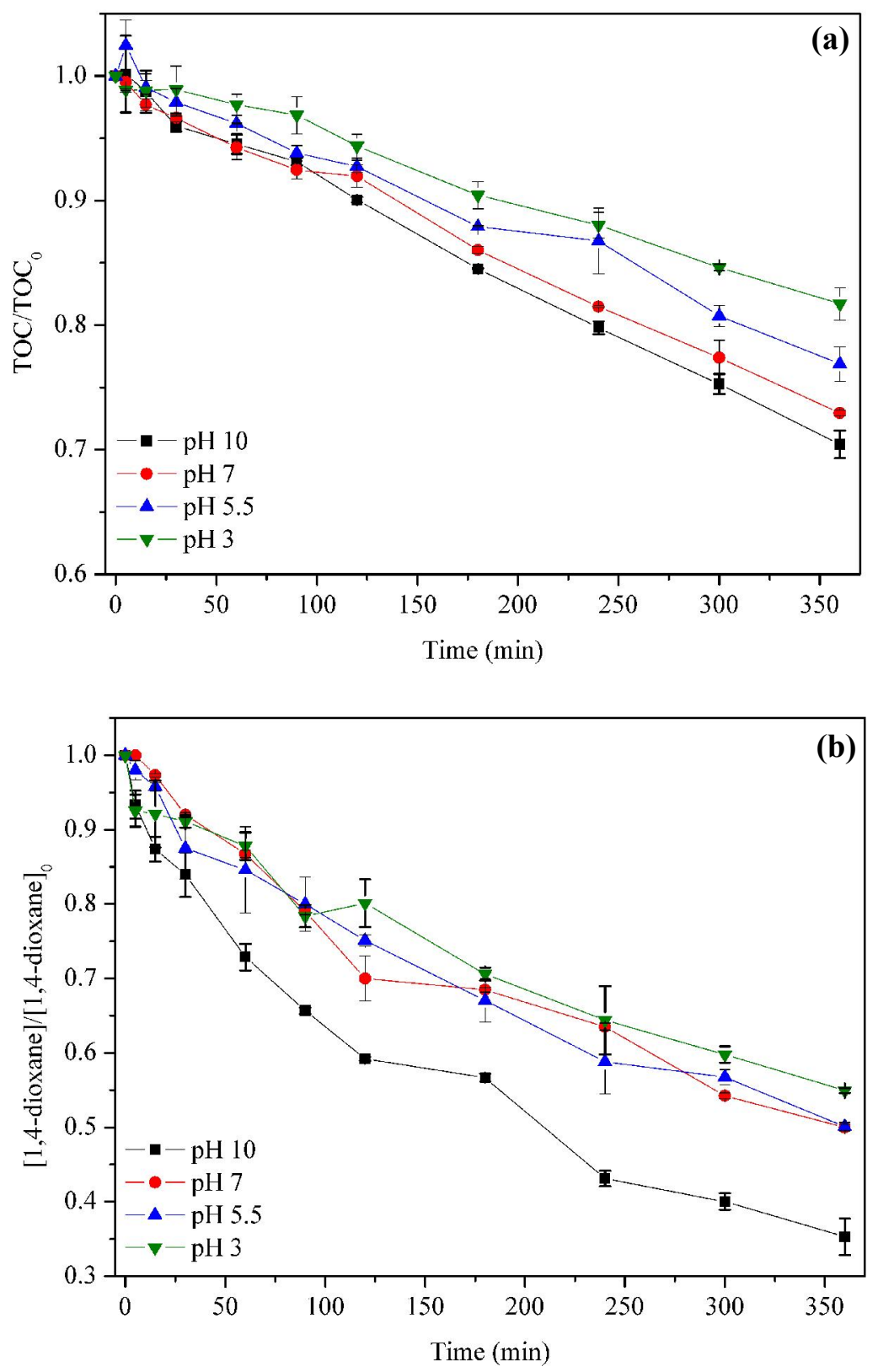


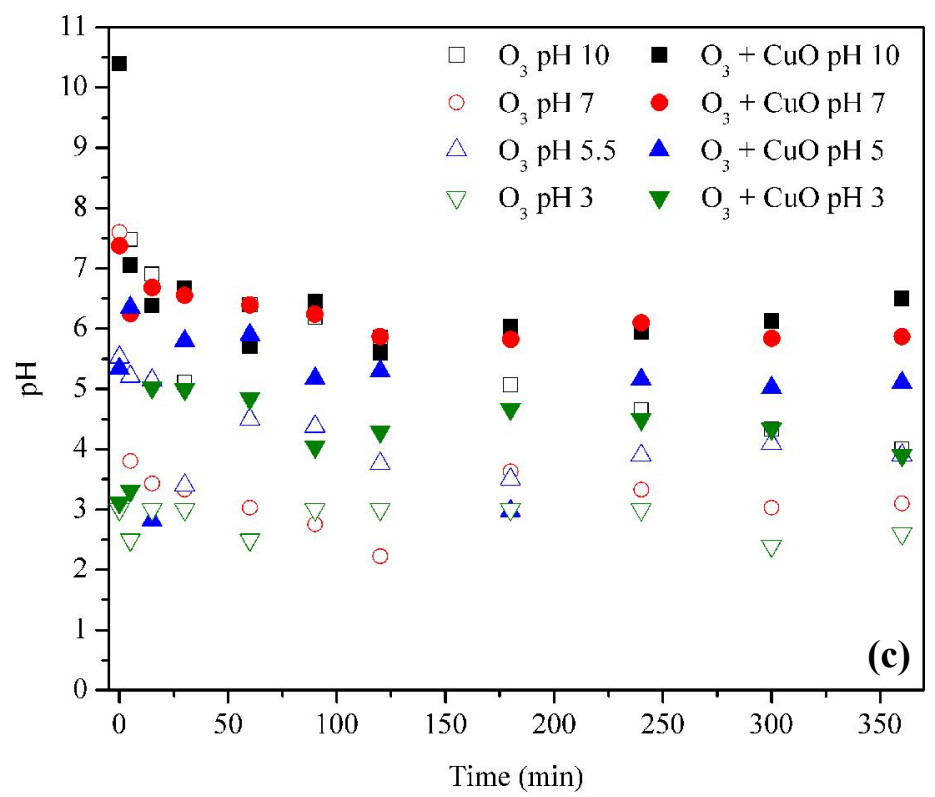

Figure S2: (a) TOC removal, (b) 1,4-dioxane removal and (c) $\mathrm{pH}$ values during 1,4dioxane treatment by catalytic ozonation at different initial $\mathrm{pH}$ values $([1,4$-dioxane $]=$ $200 \mathrm{ppm} ;$ ozone flow $=0.064 \mathrm{~m}^{3} \mathrm{~h}^{-1} ; \mathrm{T}=25 \pm 1^{\circ} \mathrm{C} ;[$ catalyst $\left.]=250 \mathrm{ppm}\right)$. 

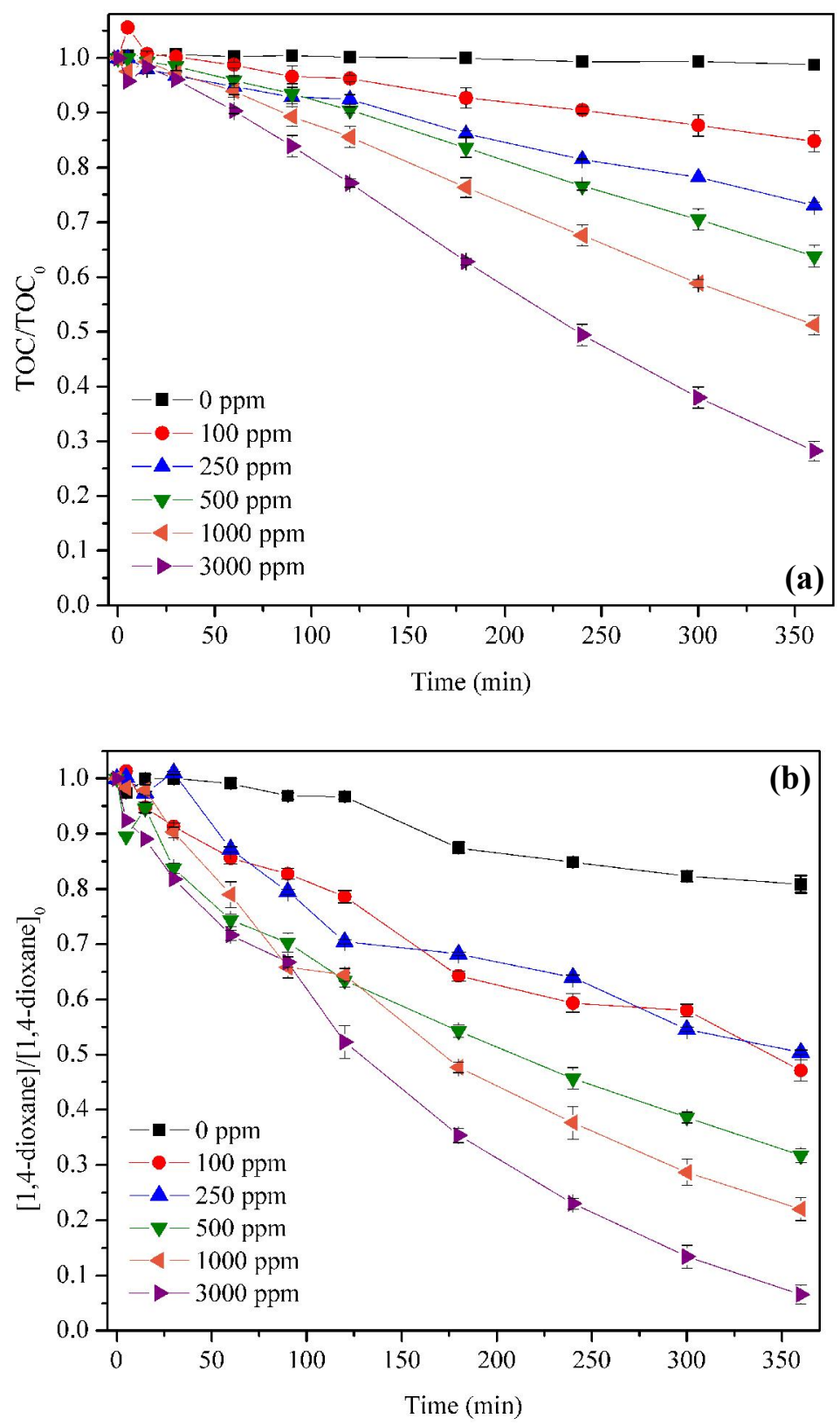

Figure S3: (a) TOC removal and (b) 1,4-dioxane removal at different catalyst dosages $\left([1,4\right.$-dioxane $]=200 \mathrm{ppm} ; \mathrm{pH}=7.0 \pm 0.5 ;$ ozone flow $\left.=0.064 \mathrm{~m}^{3} \mathrm{~h}^{-1} ; \mathrm{T}=25 \pm 1^{\circ} \mathrm{C}\right)$. 


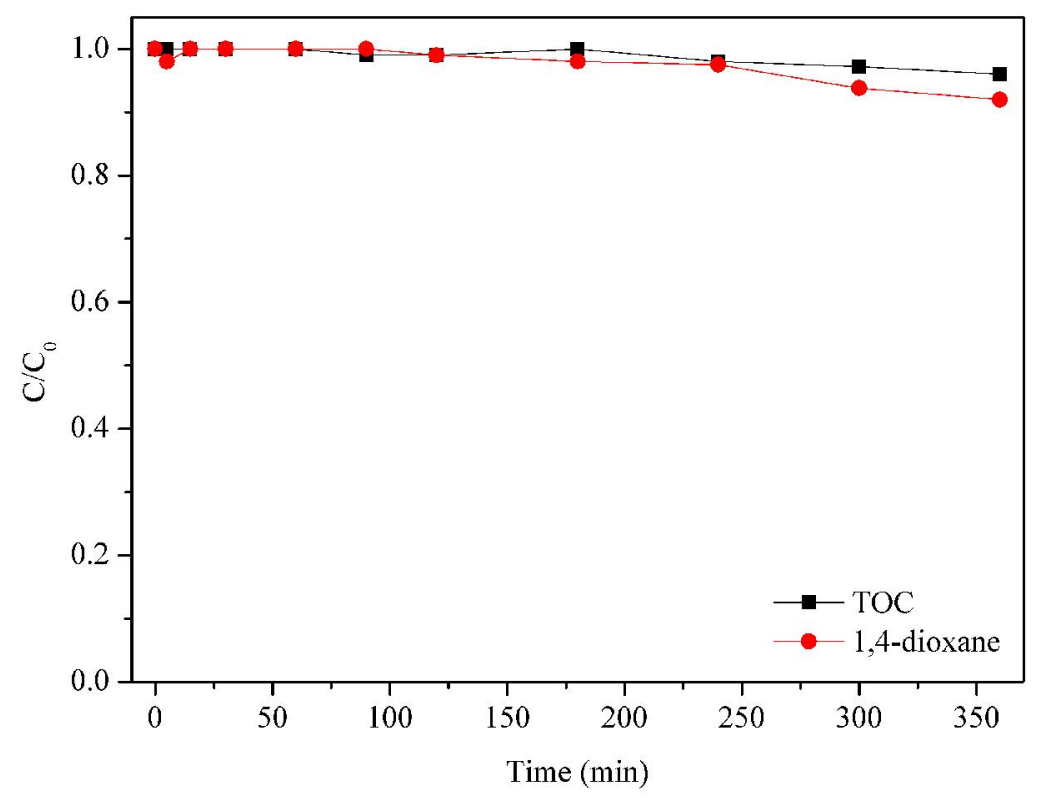

Figure S4: Kinetics of 1,4-dioxane adsorption onto $\mathrm{CuO}$ as a function of TOC and 1,4dioxane removal $\left([1,4-\right.$ dioxane $]=200 \mathrm{ppm} ; \mathrm{T}=25 \pm 1^{\circ} \mathrm{C} ;[$ catalyst $]=3000 \mathrm{ppm} ; \mathrm{pH}=$ $7.0 \pm 0.5)$. 


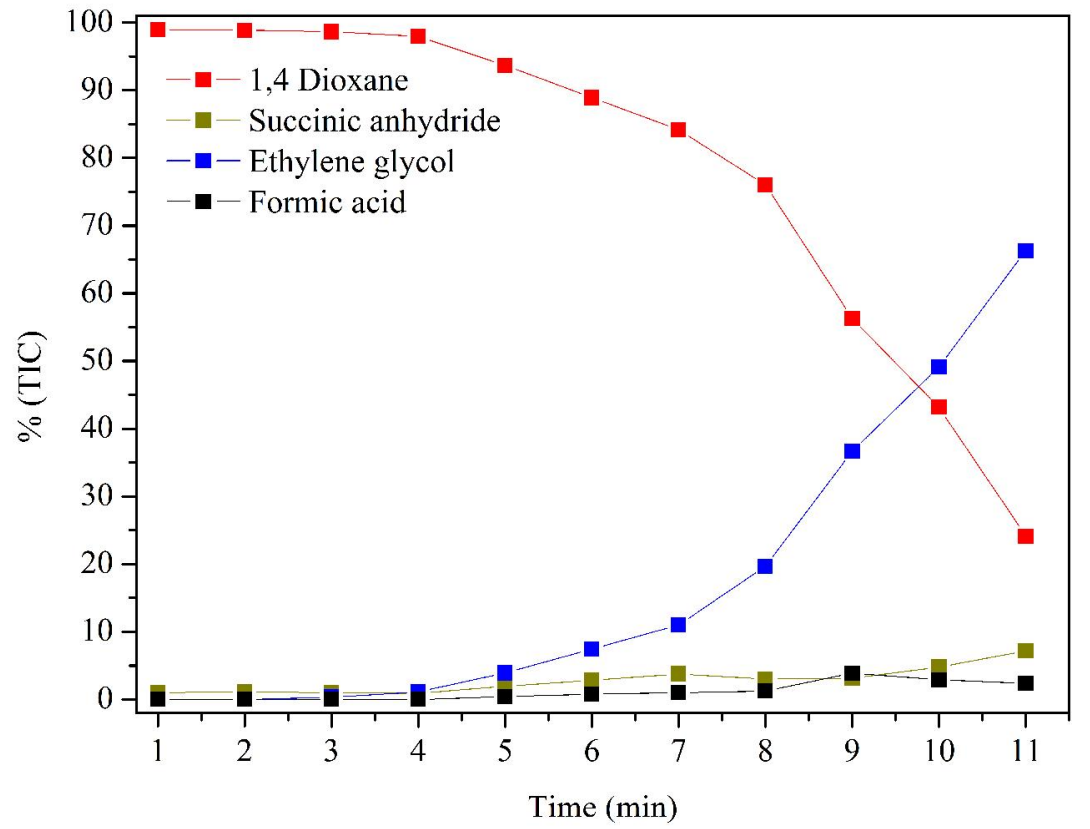

Figure S5: Evolution of the concentrations of the intermediates. 


\section{HIGHLIGHTS}

- 1,4-Dioxane can be totally removed applying catalytic ozonation with $\mathrm{CuO}$

- Superoxide radicals were responsible for 1,4-dioxane removal

- Major reaction intermediates of 1,4-dioxane were identified

- Acute toxicity during catalytic ozonation is low 